NBER WORKING PAPER SERIES

\title{
AFFIRMATIVE ACTION IN LAW SCHOOL ADMISSIONS: WHAT DO RACIAL PREFERENCES DO?
}

\author{
Jesse Rothstein \\ Albert H. Yoon \\ Working Paper 14276 \\ http://www.nber.org/papers/w14276
NATIONAL BUREAU OF ECONOMIC RESEARCH
1050 Massachusetts Avenue
Cambridge, MA 02138

August 2008

A revised version of this paper will be published in the University of Chicago Law Review in the Spring 2008 issue (vol. 75, no. 2). We are thankful for comments from workshop participants at the American Bar Foundation, the National Bureau of Economic Research, and the University of Chicago, and from Douglas G. Baird, Richard Brooks, David Gerber, Lani Guinier, John Heinz, Richard Lempert, Tracey Meares, Randall Picker, Eric Posner, Max Schanzenbach, Stephen M. Shavell, David Weisbach, Justin Wolfers, and Robert Yalen. We thank the Andrew W. Mellon Foundation for financial support. We alone are responsible for the contents and for all remaining errors. The views expressed herein are those of the author(s) and do not necessarily reflect the views of the National Bureau of Economic Research.

NBER working papers are circulated for discussion and comment purposes. They have not been peerreviewed or been subject to the review by the NBER Board of Directors that accompanies official NBER publications.

(C) 2008 by Jesse Rothstein and Albert H. Yoon. All rights reserved. Short sections of text, not to exceed two paragraphs, may be quoted without explicit permission provided that full credit, including $\odot$ notice, is given to the source. 
Affirmative Action in Law School Admissions: What Do Racial Preferences Do?

Jesse Rothstein and Albert H. Yoon

NBER Working Paper No. 14276

August 2008

JEL No. I2,J15,K30

\begin{abstract}
$\underline{\text { ABSTRACT }}$
The Supreme Court has held repeatedly that race-based preferences in public university admissions are constitutional. But debates over the wisdom of affirmative action continue. Opponents of these policies argue that preferences are detrimental to minority students -- that by placing these students in environments that are too competitive, affirmative action hurts their academic and career outcomes.

This article examines the so-called "mismatch" hypothesis in the context of law school admissions. We discuss the existing scholarship on mismatch, identifying methodological limitations of earlier attempts to measure the effects of affirmative action. Using a simpler, more robust analytical strategy, we find that the data are inconsistent with large mismatch effects, particularly with respect to employment outcomes. While moderate mismatch effects are possible, they are concentrated among the students with the weakest entering academic credentials.
\end{abstract}

To put our estimates in context, we simulate admissions under race-blind rules. Eliminating affirmative action would dramatically reduce the number of black law students, particularly at the most selective schools. Many potentially successful black law students would be excluded, far more than the number who would be induced to pass the bar exam by the elimination of mismatch effects. Accordingly, we find that eliminating affirmative action would dramatically reduce the production of black lawyers.

Jesse Rothstein

Industrial Relations Section

Firestone Library

Princeton University

Princeton, NJ 08544

and NBER

jrothst@princeton.edu

Albert H. Yoon

University of Toronto Faculty of Law

84 Queen's Park Blvd

Toronto, ON M5S 2C5

albert.yoon@utoronto.ca 


\section{INTRODUCTION}

In 1965, President Lyndon Johnson argued that the rapidly-proceeding elimination of formal, legal discrimination against African Americans was insufficient:

$[F]$ reedom is not enough. ... You do not take a person, who, for years has been hobbled by chains liberate him, bring him up to the starting line of a race and then say, "you are free to compete with all the others," and still justly believe that you have been completely fair. Thus it is not enough just to open the gates of opportunity. ${ }^{1}$

The result was an architecture of preferences in educational admissions and hiring for African Americans. Over 30 years later, heated debate over the wisdom and constitutionality of these policies continues. ${ }^{2}$ Opponents of race-conscious policies argue that formal consideration of race violates the Equal Protection Clause of the U.S. Constitution. ${ }^{3}$ But the Supreme Court has held, most recently in Grutter v. Bollinger, that equal protection objections to race-based preferences can be overcome by a compelling state interest in "diversity.",

Not surprisingly, much of the foundational scholarship on affirmative action has addressed the constitutional and normative questions. But much of the current debate turns on positive questions. Does affirmative action contribute to the advancement of African Americans in our society? If so, how much? And how great is the cost, in terms of the whites who are displaced by the use of preferences?

These questions are extremely difficult to answer. We need to know what our society would look like if affirmative action policies were absent but everything else were the same.

\footnotetext{
${ }^{1}$ President Lyndon B. Johnson, Commencement Address, To Fulfill These Rights (Howard Univ., June 4, 1965), in Public Papers of the Presidents of the United States: Lyndon B. Johnson, 1965, vol. II, 635-40 (Government Printing Office 1966).

${ }^{2}$ A Gallup Poll issued on 6/26/2005, asked "Do you generally favor or oppose affirmative action programs for racial minorities?" $50 \%$ favored; $42 \%$ opposed; $7 \%$ did not know, and 1\% refused. Available at http://institution.gallup.com.turing.library.northwestern.edu/documents/ questionnaire.aspx?STUDY=P0506026 (asking questions regarding race and gender). ${ }^{3}$ See, e.g., Justice Thomas in Grutter v. Bollinger, 539 U.S. 306, 372 (2003) (Thomas, J., concurring in part and dissenting in part); see also CAROL M. SWAIN, THE NEW WHITE NATIONALISM IN AMERICA (2002) (writing that "[a]ffirmative actions policies . . can send a powerful message to whites and blacks alike that minorities are incapable of competing on their own ....").

${ }^{4} 539$ U.S. at 325 . The Grutter Court did not, however, ratify President Johnson's argument to use affirmative action to remedy past discrimination.
} 
Unfortunately, social policy does not lend itself to controlled experiments, and inferences must be drawn from observational studies of the world outside the laboratory. Because the introduction of affirmative action coincided with many other changes in our society, isolating its impact is impossible. ${ }^{5}$

Although we cannot know what our society would look like without affirmative action, we can try to answer a narrower question: Are individual African Americans made better off by their access to preferences? Some argue that the answer is no. They claim that the existence of preferences provides (purported) beneficiaries entrée into schools and jobs that are too competitive and difficult, and that many fail who would have succeeded had they been admitted only to schools and jobs more in line with their credentials.

The importance of the so-called "mismatch effect" can be assessed only through empirical evidence. Even for this question, unverified assumptions are necessary-because affirmative action is pervasive, there is no comparison group of African Americans who are completely unaffected by preferences - but it is at least possible to imagine methodological strategies that could provide credible answers.

A recent study by Richard Sander has drawn attention for its emphasis on the importance of mismatch effects in legal education. ${ }^{6}$ A key part of Sander's argument is that affirmative action influences which schools African American students attend but has only small effects on whether these students attend law school at all. ${ }^{7}$ He contends that mismatch effects are large and that if race-based preferences were eliminated, black students' success rates - as measured by law school grades, graduation rates, bar passage rates, and post-graduation employmentwould increase dramatically. Thus, Sander argues that eliminating race-based preferences would lead to an increase in the production of successful black lawyers. ${ }^{8}$

\footnotetext{
${ }^{5}$ For an excellent overview of scholarship on the effects of affirmative action, see Harry Holzer \& David Neumark, Assessing Affirmative Action, 38 J. ECON. LiT. 483 (2000).

${ }^{6}$ See Richard H. Sander, A Systemic Analysis of Affirmative Action in American Law Schools, 57 STAN. L. REV. 367 (2004) (hereafter referred to as Systemic Analysis).

${ }^{7}$ See id. at 474 (stating that "six out of every seven blacks currently in law school would have qualified for admission at an ABA-accredited school under a race-blind system").

${ }^{8}$ See id. at 468 (claiming that "the annual production of new black lawyers would probably increase if racial preferences were abolished tomorrow") But see David L. Chambers et al., The Real Impact of Eliminating Affirmative Action in American Law Schools: An Empirical Critique
} 
These are important claims. As a policy matter, few would support affirmative action preferences in law school admissions if they were thought to harm individual African American students and to do nothing to ameliorate the shortage of black lawyers. ${ }^{9}$ Unfortunately, the current scholarship on mismatch confuses as much as it illuminates.

This article examines the mismatch hypothesis in the context of law school admissions. We make three distinct contributions. First, we provide a critical overview of the empirical literature on mismatch. We describe the strategies for estimating mismatch effects used by Sander and other scholars, and analyze the advantages and disadvantages of each.

Given the plethora of factors that influence black student performance, it is impossible to isolate the effect of mismatch. It can, however, be bounded. Our second contribution is a series of estimates that place an upper bound on the plausible importance of mismatch effects. Using a simpler, more robust empirical strategy than has been used in many recent analyses, we find that the data are inconsistent with large mismatch effects, particularly with respect to employment outcomes. While moderate mismatch effects are possible, they are concentrated among the students with the weakest entering academic credentials.

Third, we provide new estimates of affirmative action's effects on black students' access to law school in general, and to elite law schools in particular. We obtain these by simulating admissions and educational outcomes under race-blind admissions rules. Eliminating affirmative action would dramatically reduce the number of black law students, particularly at the most selective schools. Many potentially successful black law students would be excluded. These provide context for our mismatch estimates, and in combination the two estimates establish a lower bound for the contribution of affirmative action to the production of black lawyers.

of Richard Sander's Study, 57 STAN. L. REV. 1855, 1857 (2005) (concluding that eliminating racial preferences would yield a "substantial net decline in the number of African Americans entering the bar").

${ }^{9}$ See Thomas J. Kane, Misconceptions in the Debate Over Affirmative Action in College Admissions, Chilling Admissions: The AfFirmative Action Crisis AND the SEARCH FOR Alternatives 18 (Gary Orfield \& Edward Miller eds., 1998) (writing that "[t]he most damning charge against affirmative action is that it does more harm than good for the intended beneficiaries, by enticing students to attend colleges where they are unprepared for the competition"). 
We conclude that the available evidence offers only weak support for the mismatch hypothesis. Half or more of the black-white gap in law school outcomes can be attributed to differences in entering academic credentials that have nothing to do with the selectivity of the schools that students attend. What mismatch effects there may be are concentrated among the black students with the weakest entering academic credentials; moderately qualified students do not appear to experience mismatch effects even when they attend highly-selective law schools.

By contrast, the evidence indicates that racial preferences are central to maintaining racial diversity in law schools. Nearly two thirds of black law students - including nearly all of the less-qualified students who would bear the brunt of any mismatch effects - would not have attended law school at all without affirmative action. Preferences are even more important at the most selective law schools, where black enrollment would decline by 90 percent under race-blind admissions. Moreover, the relatively few black students who would remain at selective law schools without affirmative action preferences would still have substantially lower academic credentials than their white classmates, so would continue to suffer from any mismatch effects.

The effects of race-based preferences on black students' access to legal education overwhelm any negative effects of mismatch on their success rates. Many potentially successful black law students would be excluded by the elimination of preferences, far more than the number who would be induced to pass the bar exam by the elimination of mismatch effects. We conclude that the net effect of eliminating affirmative action would be to reduce the production of new black lawyers by at least 50 percent.

These estimates, and most of those in the remainder of the paper, are based on our analysis of data describing the applications, admissions, and law school records of students who applied to law school in the Fall of 1991. These are the same data relied upon by Sander and by several of his critics. ${ }^{10}$ Unfortunately, there are no comparable data available for more recent cohorts. What data are available suggest, however, that the general patterns that we describe in 1991 are substantially similar today. As we demonstrate below, in recent cohorts black students remain

${ }^{10}$ See, e.g., Daniel E. Ho, Why Affirmative Action Does Not Cause Black Students to Fail the Bar," 114 Yale L. J. 1997 (2005); Ian Ayres \& Richard Brooks, Does Affirmative Action Reduce the Number of Black Lawyers?, 57 StAN. L. ReV. 1807 (2004). One response addresses the changes since 1991, arriving at many of the same conclusions as we do. See Chambers et al., supra note 8 , at 1860 . 
nearly as underrepresented among law school applicants with very strong numeric credentials as they were in 1991.

Before we proceed, it is important to mention several caveats. First, our analysis is exclusively empirical and quantitative. We treat law schools as "black boxes," where the inputs are applicants for admission and the outputs are lawyers. We examine the effects of the quality of the inputs on that of the outputs, but do not explore the cultural, pedagogic, or other features of the law school environment that account for these effects. While our estimates here are clearly relevant to any normative evaluation, we leave to others the task of applying them to policy and the law.

Second, we focus exclusively on the admissions and success rates of black and white law students. This does not reflect a lack of concern for Hispanic, Asian, or Native American students. Rather, there are simply too few law students from these groups to permit reliable analyses.

Third, we attempt to be precise in our terminology. We refer frequently to "black" students, rather than to "African Americans," because this is the way that they are identified in the data that we study. In many cases, the "African American" label may be incorrect, as an unknown fraction of the students that we examine are foreign-born. ${ }^{11}$ We similarly refer to students who are identified as "white" in our data by that term. ${ }^{12}$

Fourth, we focus exclusively on numeric academic measures, the undergraduate grade point average and the LSAT score, as predictors of admissions decisions and academic success. Unless otherwise stated, all references to credentials or qualifications refer to these two measures. Other academic measures (e.g., personal essays, recommendation letters) and individual factors (e.g., wealth, motivation), while clearly important, are difficult to measure with any reliability. We therefore exclude these factors from our analysis. Throughout the paper, however, we discuss the impacts of this decision on our results. Importantly, these impacts are frequently predictable. It is worth emphasizing at the outset that, for all of their

${ }^{11} 10 \%$ of black law students in our data grew up in households where a language other than English was spoken.

12 Although many data sources distinguish between Hispanic and non-Hispanic whites, the survey from which our primary data set is drawn treats "white" and Hispanic as separate categories. We exclude students identified as Hispanic from all analyses. 
limitations, grade point averages and LSAT scores ${ }^{13}$ are strong predictors of both admissions ${ }^{14}$ and academic success. ${ }^{15}$

Fifth, while some have argued that the black-white test score gap is largely immutable, ${ }^{16}$ we do not take that view. We see the gap as a contingent fact of the world, ${ }^{17}$ potentially amenable to numerous policy interventions. That debate, however, is beyond the scope of this article: law schools operate with the applicants they have, among whom the black-white test score gap is substantial.

Sixth, and finally, any statistical analysis requires assumptions. Readers may find many of our assumptions implausible, and all of them are likely to be wrong in at least some details. We have two responses. One, any debate must have some discipline, and it is our view that

${ }^{13}$ On the shortcomings of standardized test scores, see JAMES CROUSE \& DALE TrusheIM, THE Case Against the SAT (1988); Charles Rooney et al., Test Scores Do Not Equal Merit: Enhancing Equity \& Excellence in College Admissions By Deemphasizing SAT and ACT Results, FairTest PubliCATIOn (1998); Edward P. St. John et al., Aptitude vs. Merit: What Matters in Persistence, 24 REV. HighER EDUC. 121 (2001). But see Christopher Jencks, Racial Bias in Testing, in The Black-White Test Score GaP 84_(Christopher Jencks \& Meredith Phillips eds., 1998) (concluding that "the skill differences [between blacks and whites] that the tests measure are real, and these skills have real consequences both at school and at work").

${ }^{14}$ See Ernest Gellhorn \& D. Brock Hornby, Constitutional Limitations on Admissions Procedures and Standards - Beyond Affirmative Action, 60 VA. L. REV. 975, 978-79 (writing that "[t]ypically, a law school's admissions committee relies heavily (but not mechanically) on an admissions index based on the applicant's undergraduate grade average and LSAT score.") ${ }^{15}$ See Linda F. Wightman, The Threat to Diversity in Legal Education: An Empirical Analysis of the Consequences of Abandoning Race as a Factor in Law School Admission Decisions, 72 N.Y.U. L. REV. 132 (1997) (hereafter referred to as Threat to Diversity) (writing that "these two variables account for approximately $25 \%$ of the variance in first-year law school grades"). See also Sander, Systemic Analysis, supra note 6, at 418-425 (pointing out the important role of numerical measures in admissions and their predictive power for future success). For discussions of the predictive power of LSAT scores for students of different races, see Lisa C. Anthony \& Mei Liu, Analysis of Differential Prediction of Law School Performance by Racial/Ethnic Subgroups Based on the 1996-1998 Entering Law School Classes, Law School Admission Council: LSAT Technical Report 00-02, Newtown, PA (2003); Linda F. Wightman \& David G. Muller, An Analysis of Differential Validity and Differential Prediction for Black, Mexican American, Hispanic, and White Law School Students, Newtown, PA: Law School Admission Council/Law School Admission Services (1990).

${ }^{16}$ See, e.g., Arthur Jensen, How Much Can we Boost IQ and Scholastic Achievement?, 39 Harvard Educational Review 1 (1969); Richard J. Herrnstein \& CHARles Murray, The Bell CuRVE (1994).

${ }^{17}$ See Stephen Jay Gould, The Mismeasure of Man (1996); James Heckman, Lessons From The Bell Curve, 103 J. POL ECONOMY 1091 (1995). 
explicitly-stated assumptions applied to actual data are preferable to guesses plucked from thin air. We try throughout to clearly articulate these assumptions, and to draw out their implications for our analysis. Two, we argue that the most likely errors in our assumptions have predictable effects on our results, and lead us to overstate the mismatch effects and understate the effect of preferences on admissions outcomes. Thus, our estimates provide an upper bound to the plausible importance of mismatch and a lower bound to the contribution of affirmative action to black enrollment.

Our primary analysis is empirical, and relies on data on entering law students. The judicial history of affirmative action is, of course, relevant to the inquiry, however. Part I provides a brief review of this history. We focus on the substantial disjunction between the Court's concerns and those that animate the policy debate.

Part II lays out the mismatch hypothesis as it applies to legal education. We also describe basic facts about the law school application and legal education process relevant to our analysis, and describe the applicant pool from which law school classes are drawn. We demonstrate that there is an enormous shortage of black applicants with strong academic credentials, and that this shortage forces all but the least selective law schools - not just the most elite law schools ${ }^{18}$ either to offer substantial preferences to black applicants or to see their black enrollments fall to near zero.

In Part III, we examine various methods of testing the mismatch hypothesis. We discuss the merits and demerits of alternative approaches and argue for our chosen approach, involving comparisons of the outcomes of black and white students with the same entering credentials. We argue that this approach likely overstates the impact of mismatch effects, thereby providing an upper bound to their importance. Part IV reports the results of our analysis of mismatch.

In Part $\mathrm{V}$, we present simulations of law school admissions as they would have occurred without affirmative action. These simulations show that race-blind admissions would have yielded dramatically fewer black entering law students, particularly in the more selective schools.

\footnotetext{
${ }^{18}$ See Sander, Systemic Analysis, supra note 6, at 417 (claiming that "the only schools that truly
} benefit from the preferential policies are those at the top-perhaps the top forty law schools.") 
Part VI combines this simulation with our analysis of mismatch, permitting us to assess the relative magnitudes of mismatch and displacement effects. We draw an important distinction between two of our results: In the absence of affirmative action, the fraction of black law students who drop out of law school or fail the bar exam would decrease substantially. But this effect would derive primarily from the exclusion of many black students who have low probabilities of success; there is only weak evidence that any individual black law student's prospects would be improved. Without preferences, the production of black lawyers-measured either in raw numbers or as a percentage of law school applicants-would fall dramatically.

Part VII examines how the facts that we document might have changed since the 1991 cohort that is the focus of our analysis. While there are more black law school applicants with moderately strong LSAT scores today than in 1990-1991, black students are still dramatically underrepresented among applicants with the highest LSAT scores, and the general patterns that we describe likely persist today.

\section{Part I. An Overview of the Legal and Policy Debates Over Affirmative Action}

Constitutional and policy debates over affirmative action have, for the most part, proceeded on separate tracks. Where the jurisprudence has centered on the importance of diversity as a compelling state interest, ${ }^{19}$ the policy debate has focused on the rationales for affirmative action

\footnotetext{
${ }^{19}$ Justice Powell was the first to hold that diversity is a compelling state interest, in Regents of the University of California v. Bakke. See 438 U.S. 265, 311-12 (1978) (holding that "the attainment of a diverse student body . . . clearly is a constitutionally permissible goal for an institution of higher education.") No other justice signed on to this portion of the opinion, however, and the status of the diversity rationale remained murky. Lower courts have subsequently debated the meaning of Bakke. See Hopwood v. State of Texas, 78 F.3d 932, 944 (1996) (finding diversity not a compelling state interest), aff'd, 236 F.3d 256 ( ${ }^{\text {th }}$ Cir. 2000 , en banc). But see Smith v. Univ. of Wash., 233 F.3d 1188, 1198 (9th Cir. 2000) (upholding diversity as a compelling state interest). The Supreme Court clarified the matter in Grutter v. Bollinger, writing that "[t]oday we endorse Justice Powell's view that student body diversity is a compelling state interest that can justify the use of race in university admissions," 539 U.S. 306, 325 (2003)
} 
that are more compensatory in nature. ${ }^{20}$ Proponents argue that affirmative action helps the students who are admitted to selective schools via preferences, and that this has spillover effects on other minorities and on American society at large. ${ }^{21}$

Opponents counter that affirmative action stigmatizes its beneficiaries, ${ }^{22}$ promotes a raceconscious rather than race-blind society, ${ }^{23}$ and generates resentment between ethnic groups. ${ }^{24}$ They also dispute the premise that affirmative action can foster the creation of minority role models. Rather, some argue for what is called the mismatch hypothesis, which posits that

${ }^{20}$ See, e.g., CORNEL WEST, RACE MATTERS 65 (1993) (claiming affirmative action is worth preserving to alleviate the "persistence of discriminatory practices.") ${ }^{21}$ See, e.g., Randall Kennedy, Persuasion and Distrust: A Comment on the Affirmative Action Debate, 99 HARV. L. REV. 1327, 1329 (1986) (arguing that affirmative action benefits AfricanAmericans through "the accumulation of valuable experience, the expansion of a professional class able to pass its material advantages and elevated aspirations to subsequent generations, the eradication of debilitating stereotypes, and the inclusion of black participants in making consequential decisions affecting black interests"). The "spillover" argument can be seen in amici briefs filed with the Supreme Court in the Grutter case and the companion Gratz v. Bollinger, 539 U.S. 244,270 (2003) by groups of military officers and businesspeople. See e.g., Brief of 65 Leading American Businesses as Amici Curiae in Support of Respondents, Grutter v. Bollinger, 123 S. Ct. 2325, 2340 (2003) (2003 WL 399056); Brief of General Motors Corp. as Amicus Curiae in Support of Respondents, Grutter v. Bollinger, 123 S. Ct. 2325, 2332-33 (2003) (2003 WL 399096); Consolidated Brief of Lt. General Julius W. Becton, Jr. as Amici Curiae in Support of Respondents, Grutter v. Bollinger, 123 S. Ct. 2325, 2340 (2003) (2003 WL 1787554). These briefs argue that affirmative action preferences promote a class of highly visible, successful minorities and that the existence of such role models promotes the continued integration of African Americans into the upper reaches of our society and economy. See also Susan Sturm \& Lani Guinier, The Future of Affirmative Action: Reclaiming the Innovative Ideal, 84 CAL. L. REV. 953, 1022-34 (1996) (arguing that affirmative action promotes a "functional theory of diversity," emphasizing the positive benefits of diversity in politics, schools, and the work-place).

${ }^{22}$ See Grutter, 539 U.S. 306, 353 (2003) (J. Thomas, dissenting) (writing that "the majority of blacks are admitted to the Law School because of discrimination, and because of this policy all are tarred as undeserving."). This has been formalized by Steven Coate and Glenn Loury, Will Affirmative Action Policies Eliminate Negative Stereotypes? 83 AMER. ECON. REV. 1220 (1993), who argue that affirmative action can promote what is known as "statistical discrimination" against academically successful minorities. See also Patricia Williams, Metro Broadcasting, Inc. v. FCC: Regrouping in Singular Times, 104 HARV. L. REV. 525, 541 (1990).

${ }^{23}$ See Grutter, 539 U.S. 306, 353 (2003) (J. Thomas, dissenting) (writing that "every time the government places citizens on racial registers and makes race relevant to the provision of burdens or benefits, it demeans us all").

${ }^{24}$ See Adarand Constructors v. Pena, 515 U.S. 200, 241 (writing that affirmative action policies "provoke resentment among those who believe that they have been wronged by the government's use of race"). See also ThOmas SOWELl, Civil Rights: RHETORIC TO REALITY? 118-19 (1984) 
affirmative action harms minorities by placing them in academic environments for which they are unprepared, thereby causing them to perform less well than they would have if they had not received preferential treatment in the first place. ${ }^{25}$ Richard Sander's analysis of law school admissions $^{26}$ is a recent example; he argues that black students would do better in law school if they did not receive affirmative action preferences, and that the legal education system produces fewer black lawyers than it would if admissions were race blind. ${ }^{27}$

The mismatch hypothesis undercuts arguments for the remedial use of preferences, as advanced by President Johnson, suggesting that they do more harm than good and that a shift to race-blind admissions could help to promote, rather than hinder, the goals of economic integration and African American progress that are cited in the Grutter and Gratz amici briefs. ${ }^{28}$

Acceptance of the mismatch hypothesis need not directly impact the constitutional justification for affirmative action: It might be the case that admitting black students with poor qualifications into elite schools fosters a diverse learning environment but hurts black students themselves. If so, by the Court's logic, affirmative action might remain permissible. On the other hand, the Court might very well conclude that affirmative action, if it harms minority students, fails its own test of not "unduly harm[ing] members of any racial group."29

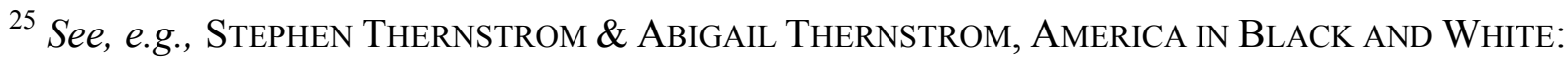
ONE NATION, INDIVISIBILE 406 (1997) ("When students are given a preference in admissions because of their race . . . they are jumping into a competition for which their academic achievements do not qualify them, and many find it hard to keep up"). See also Clyde W. Summers, Preferential Admissions: An Unreal Solution to a Real Problem, 2 U. TOL. L. REV. 377,395 (1970) (claiming that "the preference given to a minority student seriously jeopardizes his chances of getting a good legal education").

${ }^{26}$ See Sander, Systemic Analysis, supra note 6, at 371 (writing, "in one realm after another the system of racial preferences ... produces more harms than benefits for its intended beneficiaries.")

${ }^{27}$ The Sander article generated significant reaction from other scholars, most of it critical, on both methodological and normative grounds. See Ho, supra note 10; Chambers, et al, supra note 8/; Michele L. Dauber, The Big Muddy, 57 StAN. L. REV. 1899 (2005); Ayres \& Brooks, supra note 10; David B. Wilkins, A Systematic Response to Systemic Disadvantage: A Response to Sander, 57 StAN. L. REV. 1915 (2005); Kevin R. Johnson \& Angela Onwauchi-Willig, Cry Me a River: The Limits of "A Systemic Analysis of Affirmative Action in American Law Schools, ” 7 AFR.-AM. L. \& POL'Y REP. 1 (2005).

${ }^{28}$ See footnote 21.

${ }^{29}$ Grutter, 539 U.S. at 341. 
As a practical matter, however, it is difficult to imagine that preferences for black students would survive for long if the factual claims of its opponents came to be generally accepted. Few would support a policy that they thought inflicted harm on underprivileged minority students for the purpose of helping already-advantaged white students, and it seems at least plausible that a demonstration of a deleterious effect of affirmative action would change some or all of the Gratz majority's thinking on the subject.

Unfortunately, evidence regarding the mismatch hypothesis has been difficult to assemble. As we discuss in Section III, mismatch effects are often inferred from evidence that is at least equally consistent with alternative explanations.

We do not attempt a precise measurement of mismatch here. For reasons we discuss below, the available data do not permit this. Nevertheless, observed patterns of student admissions and performance can be used to place an upper bound on the plausible magnitude of mismatch effects. We discuss our strategy for doing so in Part III. Before doing so, we discuss the mismatch hypothesis in more detail, and particularly its application to law school admissions, in Part II.

\section{Part II. The Mismatch Hypothesis and Legal Education}

\section{A. Defining Mismatch}

We follow Richard Sander's characterization of the mismatch hypothesis:

[I]f there is a very large disparity at a school between the entering credentials of the 'median' student and the credentials of students receiving large preferences, then the credentials gap will hurt those the preferences were trying to help. A large number of those receiving large preferences will struggle academically, receive low grades, and actually learn less in some important sense than they would have at another school where their credentials were closer to the school median. The low grades 
will lower their graduation rates, bar passage rates, and prospects in the job market. ${ }^{30}$

This is a claim about the causal effect of attending a highly selective school on a student's outcomes. It is worth walking through a version of the story often presented about how mismatch effects arise. Consider a black student who would prefer to attend School X and whose second choice is the lower-ranked school Y. Students at School X are more likely to graduate and to pass the bar exam, and tend to have better placements into internships, clerkships, and post-graduation jobs. This reflects, at least in part, stronger students at School X: Our hypothetical applicant's LSAT score places her near the bottom of the School-X distribution but near the top of the School-Y distribution.

Under race-blind admissions, our student is denied admission to School $\mathrm{X}$ but accepted to School Y. She attends School Y, where she discovers herself to be better prepared for the firstyear courses than are most of her classmates. She attains good grades, is invited to serve on the law review, earns a summer associate position at a well-respected firm, and graduates near the top of her class.

With affirmative action, however, our student is also admitted to School X. There, she is a proverbial small fish in a big pond ${ }^{31}$ : Nearly all of her white classmates enter law school with stronger academic credentials, more experience with legal concepts, and stronger writing skills than she has. She works hard, but the academic demands at School X are much higher than at School Y, and by the end of the first year she finds herself near the bottom of her class. She does not make law review, and will graduate - if she does — without academic distinction.

We can accept, arguendo, that this is the consequence of affirmative action for our student's prospects. If so, the mismatch hypothesis is certainly plausible: Attending School X may demoralize her and lead her to doubt her own abilities. She may decide to drop out after her first

${ }^{30}$ Richard H. Sander, Reply to Critics, 57 STAN. L. REV. 1963, 1966 (2005).

31 The mismatch hypothesis is sometimes referred to as the "Frog Pond" hypothesis, following from the reasoning that it is better to be a big fish (or, apparently, frog) in a small pond than a small fish in a large pond. See Thomas J. Espenshade et al, The Frog Pond Revisted: High School Academic Context, Class Rank, and Elite College Admission, 78 Sociology of EduC. 269-293 (2005). Outside of the debate over affirmative action, scholars generally presume that high-achieving peers will help rather than hurt an individual's performance. See, e.g., Bruce Sacerdote, Peer Effects with Random Assignment: Results for Dartmouth Roommates, 116 Q. J. ECON. 681 (2001). 
year. If she remains in law school she may miss key concepts in her struggle to keep up with classes, and ultimately may have trouble passing the bar exam. Finally, her transcript, while from the more prestigious School X, will not show a record of strong performance, potentially hurting her employment prospects. ${ }^{32}$

\section{B. Mismatch in Law School}

Questions about the role of admissions preferences and mismatch are particularly important in legal education. Many law graduates become prominent in government, business, and of course, law. Given this impact, "role model" arguments for affirmative action are particularly relevant here. Finally, several observers have argued that diversity is especially important to the legal learning experience. ${ }^{33}$

There are several aspects of legal education and admissions that might be expected to accentuate mismatch effects. The first is the importance of the bar exam threshold to the career prospects of law graduates. If attending a selective school reduces a student's chances of being able to pass the bar exam, this can be taken as a prima facie harm to that student. ${ }^{34}$ This hypothesis is plausible: it is well known that highly-ranked, selective law schools devote relatively little of their curricula to bar exam preparation, often replacing it with more theoretical

${ }^{32}$ A central assumption of this story is that a student cannot predict the deleterious effects that School X will have on her. If she could, she would simply decline her admission offer from School X and instead attend School Y, where the availability of race-based preferences would have no effect on her. There are more complex models of the education process, however, in which the availability of preferences can hurt students who do not themselves take advantage of them. See Coate and Loury, supra note 22 (on "statistical discrimination"); Claude Steele \& Joshua Aronson, Stereotype Threat and the Intellectual Test Performance of African Americans, 69 J. PERSONALITY \& SOC. PSYCH. 797 (1997) (on "stereotype threat").

${ }^{33}$ See, e.g., Kent Syverud, 5 MiCH. J. RACE \& L. 451, 452 (1999), Expert Report Grutter, et al. v. Bollinger, et al., No. 97-75928 (E.D. Mich.) (noting that "racial diversity in the Socratic classroom strongly fosters the kind of thinking that the best lawyers need to be able to do").

${ }^{34}$ Attending a selective school might raise or lower a student's probability of taking the bar exam, if it affects her propensity to pursue a career other than the practice of law. This is a separate issue. So is the question of whether the bar exam difficulty or content is set appropriately; regardless, students hoping to practice law must pass the exam. 
or interdisciplinary topics. ${ }^{35}$ Although students at these schools often take bar review courses, the shortage of bar relevant material in their coursework may reduce weaker students' probabilities of passing the bar exam.

Second, law students' employment outcomes depend heavily on their performance relative to their classmates, particularly in the first year of law school when courses are typically exambased and graded on strict curves. ${ }^{36}$ Even in the absence of mismatch effects on students' actual achievement, any measure that is computed in relation to others in the class will tend to penalize students whose entering academic credentials are relatively low, and a given student will tend to achieve a lower class rank when she attends a more selective school. ${ }^{37}$ This will hurt her chances of obtaining many of the coveted law school accolades: law review ${ }^{38}$ summer internships, judicial clerkships, and post-graduation jobs. ${ }^{39}$

Finally, the style of instruction in law school may promote mismatch effects. Many professors call on students randomly to analyze cases or otherwise demonstrate their knowledge,

${ }^{35}$ See, e.g., Alex M. Johnson, Jr., Think Like a Lawyer, Work Like a Machine: The Dissonance Between Law School and Law Practice, 64 S. CAL. L. REV. 1231, 1245 n.59 (1991) (contending that elite law schools do not prepare their students for the bar). See also RoBERT STEVENS, LAW SCHOOL: LEGAL EDUCATION IN AMERICA FROM THE 1850'S TO THE 1980's (1983) (describing how law schools previously emphasized the importance of practical training during law school); Harry T. Edwards, The Growing Disjunction Between Legal Education and the Legal Profession, 91 MicH. L. REV. 34 (1992).

${ }^{36}$ See, e.g., Philip C. Kissam, Law School Examinations, 42 VAND. L. REV. 433, 463 (1989) (discussing how legal employers use class ranks and law review status to screen and select law students).

${ }^{37}$ Wightman documents a strong relationship between LSAT scores and grade point averages within specific law schools. See Linda F. Wightman, Beyond FYA: Analysis of the Utility of LSAT Scores and UGPA for Predicting Academic Success in Law School. Law School Admission Council: Research Report 99-05, Newtown, PA, p.15-17 (1990) (hereafter referred to as Beyond FYA).

${ }^{38}$ See, e.g., Roger C. Cramton, "The Most Remarkable Institution”: The American Law Review, 36 J. LEGAL EDUC. 1, 5 (1986) (noting that "the initial selection of student editors was based on academic performance in the first year of law school"). In recent years, law review selection has been supplemented or supplemented by a writing competition. See id. at 6 .

${ }^{39}$ Some employers may consider job candidates only from highly-ranked schools. This could create a selective-school premium that is unrelated to achievement. But see Sander, Systemic Analysis, supra note 6, at 460 (claiming that "law school grades are quite important, perhaps more important than law school prestige in determining who gets what jobs"). 
which requires students to engage in a repeated question-and-answer exchange. ${ }^{40}$ This style of teaching may have the effect of drawing attention to students who have difficulty with the course material, thereby reinforcing the demoralization that tends to follow from being underprepared. ${ }^{41}$ There may be a racial dimension to this pedagogy: If black students in the class are generally less prepared than whites, others in the class may form negative stereotypes about all black students, ${ }^{42}$ and the black students themselves may internalize this and come to consider themselves as representatives of their race, rather than simply as students, when participating in class. ${ }^{43}$ Because blacks will tend to have lower academic qualifications than whites at the same schools even in the absence of affirmative action - a point we elaborate on below - a toxic interaction of the Socratic method with "stereotype threat" may depress black students" performance even without mismatch. But affirmative action will expand the black-white qualifications gap within any school, accentuating these tendencies and perhaps making the selective school effect more negative for black students.

One important aspect of legal education substantially complicates the analysis of mismatch. There are no unselective law schools ${ }^{44}$, and a large fraction of the students who apply to law school each year - over 40 percent in $1990-91^{45}$ - are not admitted to any law school. Thus, law

${ }^{40}$ See Lawrence M. Grosberg, Standardized Clients: A Possible improvement for the Bar Exam, 20 GA. ST. U. L. REV. 841, 852 (2004) (noting that "[t] he vast majority of teachers of [first year courses] use standard casebooks and some variation of the Socratic method").

${ }^{41}$ A related issue is that the Socratic method may contribute to the creation of a law school culture that depresses minority students' and women's performance, independent of any mismatch effects. See, e.g., Morrison Torrey, You Call That Education?, 19 Wis. Women's L.J. 93, 105 (2004) and Lani Guinier et al., Becoming Gentlemen: Women's Experiences at One Ivy League Law School, 143 U. PA. L. REV. 1, 4 (1994) (claiming the Socratic method is disproportionately harmful to women and minorities).

${ }^{42}$ See Coate and Loury, supra note 22, at 1221.

${ }^{43}$ See Shelby Steele, The Content Of Our Character (1990); Claude M. Steele, A Threat in the Air: How Stereotypes Shape the Intellectual Identities and Performance of Women and African Americans, 52 AMER. PsYcH. 613 (1997); Claude M. Steele \& Joshua Aronson, Stereotype Threat and the Test Performance of Academically Successful African Americans, in Black-White Test Score GAP (C. Jencks \& M. Phillips, eds., 1998).

${ }^{44}$ Only 3 of 181 schools accepted more than $50 \%$ of their applicants in 2007 , and the highest acceptance rate - Thomas M. Cooley Law School- was 68.5\%. See http://www.ilrg.com/ rankings/law/index.php/4/asc/Accept/2007 (last visited February 23, 2007).

${ }^{45}$ These figures are based on the authors' analysis of data from a Memorandum from Beverly Barnes and Robert Carr (Law School Admission Services) to "Admission Officers," (January 1991) (on file with authors). 
school stands in contrast to undergraduate education, where any student can attend college if she wishes $^{46}$ and the admissions policies of selective colleges affect only which schools she can select among. Law schools' admissions policies determine not just which school an applicant will attend but whether she will have the opportunity to become a lawyer at all. Importantly, we demonstrate below that black applicants are much more likely to gain admission to at least one law school than are white students with the same academic credentials. The black students so admitted would not have had the opportunity to attend without preferences, and would have been forced to make other career choices. We focus on the academic and career outcomes of students who actually attend law school, but are unable to separately identify the average outcomes of those black students who would have matriculated even without preferences. This might well be higher than the average for all black students, if those who would be displaced have lower outcomes than those who would not.

We find that there are identifiable categories of students - those with very low LSAT scores and undergraduate grades - for whom success in law school is unlikely, and among whom dropout rates are high and bar passage rates are low. One can think of the option of attending law school for such a student as a lottery ticket that pays off with a license to practice law. ${ }^{47}$ It is tempting to conclude that these students would have been better off not attending law school. But this conclusion is not supported by the evidence that we present. Assessment of this would require us to know the career paths that these students would have followed had they not gone to law school. Because we know little about this counterfactual, we focus on identifying the effects of attending selective law schools relative to unselective law schools, not on the effects of attending law school at all.

\footnotetext{
${ }^{46} 22 \%$ of colleges and universities have "open admissions," and only $68 \%$ use admissions test scores for admissions. See Thomas D. Snyder, Digest of Education Statistics: 2000, 341 tbl. 309 (2001).

${ }^{47}$ Of course, even students who do not pass the bar exam may have successful careers. At issue is whether the prospects of a student who may not be able to pass the bar exam are better or worse than they would be if she never attended law school in the first place.
} 


\section{The Law School Applicant Pool}

A central fact about law school admissions is that very few black students apply to law school with top academic credentials. In this and subsequent sections, we use two sources of information to characterize the composition and experiences of the cohort that entered law school in 1991, about which we have richer data than are available for more recent cohorts. The first is a tabulation created by the Law School Admission Council, which every year categorizes law school applicants by race, LSAT score range, and undergraduate GPA range. We thus know, for example, that in the 1990-1991 admissions cycle, there were 3,105 white students and 40 black students with LSAT scores between 38 and $41^{48}$ and GPAs between 3.25 and 3.49 who applied to law school. ${ }^{49}$ The tabulation, which we refer to as the "grid data," also reports the number of students in each cell who were admitted to at least one school and who ultimately matriculated.

Our second data source is the Bar Passage Study (hereafter referred to as BPS), a survey of students who entered law schools in 1991 conducted by the Law School Admission Council. ${ }^{50}$ Approximately $62 \%$ of entering students at accredited law schools responded to the survey, ${ }^{51}$ which collected information about students' entering credentials, law school grades, graduation, and bar passage. Like the grid data, the BPS is limited in various ways, described below. Nevertheless, in combination the two data sets permit a reasonably comprehensive understanding of the admissions process and of law school outcomes, taking us from the applicant pool through

48 The LSAT was graded on a 10-48 scale until 1991, when it changed to the 120-180 scale in use today. 38 and 41 were the $79^{\text {th }}$ and $91^{\text {st }}$ percentiles, respectively, of the 1990-1991 distribution. See Memorandum from Stephen W. Luebke (Law School Admission Services) to "LSAT Score Recipients," (April 29, 1991) (on file with authors) . In 2003-2004, these percentiles corresponded to scores of approximately 159 and 163. See Memorandum from Lisa Stilwell (Law School Admission Council) to Richard Adams and ten other recipients (May 14, 2004) (on file with authors).

${ }^{49}$ See Barnes \& Carr, supra note 45.

${ }^{50}$ See Linda F. Wightman, LSAC National Longitudinal Bar Passage Study, LSAC Research Report (1998).

${ }^{51}$ See Linda F. Wightman, User's Guide: LSAC National Longitudinal Data File (1999), at 2. By comparing the distribution of entering credentials among BPS respondents with those among all matriculants included in the LSAC grid data, we can compute response rates in each raceLSAT-GPA cell. BPS respondents appear to be generally representative, with perhaps slight overrepresentation of high-scoring students. All of our analyses of the BPS data weight them to match the LSAT-undergraduate GPA distributions seen in the grid data. 
admissions, matriculation, graduation, bar exams, and finally to employment in the year after graduation. No comparable data are available for more recent cohorts of law students. Thus, although the world has certainly changed in important ways since 1991, most of our analysis focuses on this cohort. In Part VII, we use the grid data for more recent cohorts to examine the relevance of our analysis to more recent law school applicants.

The gap in academic credentials between black and white students begins long before law school. Large black-white gaps in achievement arise in kindergarten or even earlier. ${ }^{52}$ By fourth grade, the time of the earliest administration of the National Assessment of Educational Progress (NAEP), 41 percent of white students read at a "proficient" level and 76 percent meet a "basic" standard, while only 13 percent of black students are proficient and 42 percent basic. ${ }^{53}$ Blackwhite gaps are similar in eighth grade.

While nearly all children complete the eighth grade, not all graduate high school; of those who do, not all enter college; and of those who enter college not all will graduate. At each point, black students are less likely to proceed than white students, and those who do have lower average qualifications than do their white counterparts. Blacks constitute 16.1 percent of elementary and secondary school students ${ }^{54}, 14.1$ percent of high school graduates, 10.3 percent of entering college students, ${ }^{55}$ and 6.2 percent of college graduates. ${ }^{56}$

Only a small fraction of college graduates apply to law school. While 1,081,280 students were granted four year college degrees in $1991^{57}$, only 92,648 applied to ABA-approved law schools in 1990-1991. ${ }^{58}$ But 7.9 percent of all law school applicants were black ${ }^{59}$, indicating that black graduates are somewhat more likely to consider attending law school than are whites.

${ }^{52}$ See Roland G. Fryer, Jr and Steven D. Levitt, The Black-White Test Score Gap Through Third Grade, 8 AMER. L. \& ECON. REV. 249 (2006); Meredith Phillips et al, Does the Black-White Test Score Gap Widen After Children Enter School?, in THE BLACK-WHITE TEST SCORE GAP (1998) (Christopher Jencks and Meredith Phillips, eds.).

${ }^{53}$ See M. Perie et al, The Nation's Report Card: Reading 2005, NATL. CTR. EduC. StAT. 2006451, p.4 (2005).

${ }_{55}^{54}$ See Snyder, supra note 46 , at 58 tbl. 44.

${ }^{55} \mathrm{Id}$. at 214 tbl. 184.

${ }^{56}$ Id. at 312 tbl. 312 .

${ }^{57}$ Id. at 312 tbl. 265.

${ }^{58}$ See Barnes and Carr, supra note 45.

${ }^{59}$ See id. 
LSAT scores provide a useful, albeit limited, measure of the academic qualifications of law school applicants, and highlight significant differences between black and white applicants. 55 percent of all black law school applicants in 1990-1991 had LSAT scores below $25,{ }^{60}$ as compared with 8 percent of whites; 32 percent of whites and only 5 percent of blacks had scores above $34 .{ }^{61}$ An important consequence of the large differences in the distribution of test scores is that black students are severely underrepresented among students who earn the high LSAT scores typical of students admitted to the most selective law schools. Figure 2.1 shows the fraction of LSAT-takers who were black at each score level. Blacks comprised only 1.5 percent of applicants with LSATs at or above $38 ; 1.1$ percent of those with scores at or above 42 ; and 0.8 percent of those with scores at or above $46 .{ }^{62}$ To illustrate how these figures contrast with white applicants, 89 percent of students admitted to Yale Law School in the 1990-1991 admissions cycle had LSAT scores of 41 or higher. ${ }^{63}$

${ }^{60}$ On interpretation of the 10-48 scale in use in 1990-91; see note $/ 48$.

${ }^{61}$ See id.

${ }^{62}$ See id.

${ }^{63}$ See The Official Guide to U.S. Law Schools, 1992-1993, 411 (1993) (indicating that 364 of 407 admitted students were at the $91^{\text {st }}$ percentile or above in 1990-1991). The $91^{\text {st }}$ percentile of scores given in 1990-1991 was 41. See Luebke, supra note 48. 
Figure 2.1: BLACK SHARE OF 1990-91 BLACK AND WHITE LAW SCHOOL APPLICANTS, BY LSAT SCORE RANGE

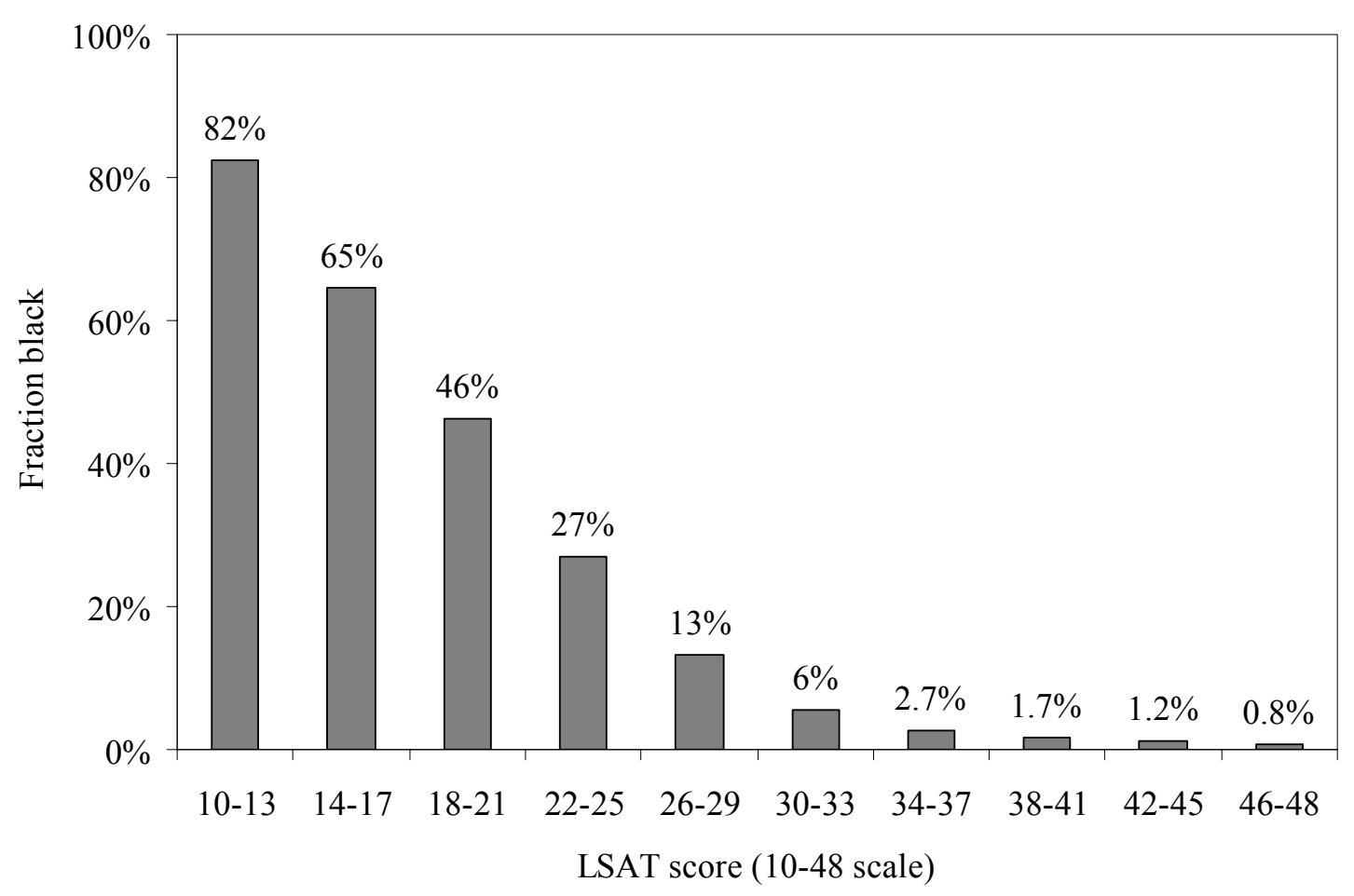

Source: Barnes and Carr, supra note 45.

The second important variable considered in admissions is the undergraduate GPA (which some schools may adjust to reflect the quality of the college). The grid data show that in each LSAT range the GPA distribution among black applicants is lower than that among whites. Table 3.1 shows, for example, the portion of the grid describing the aforementioned applicants with LSAT scores between 38 and 41. Of applicants with LSAT scores in this range, half of whites and only $30 \%$ of blacks have GPAs above 3.0 (corresponding to a "B" average). 


\section{TABle 2.1: UndergraduATE GPA Distribution OF White AND BLACK APPLICANTS WiTH LSAT SCORES 38-41}

\begin{tabular}{|c|c|c|c|c|c|}
\hline & \multicolumn{2}{|c|}{ Whites } & \multicolumn{2}{|c|}{ Blacks } & \multirow{2}{*}{$\begin{array}{l}\text { Black } \\
\text { share }\end{array}$} \\
\hline & & nulative & & nulative & \\
\hline & (1) & (2) & (3) & (4) & (5) \\
\hline \multicolumn{6}{|l|}{ GPA } \\
\hline Below 2.00 & 49 & $0.4 \%$ & 2 & $0.8 \%$ & $3.9 \%$ \\
\hline $2.00-2.24$ & 225 & $2.0 \%$ & 11 & $5.3 \%$ & $4.7 \%$ \\
\hline $2.25-2.49$ & 601 & $6.3 \%$ & 26 & $16.0 \%$ & $4.1 \%$ \\
\hline $2.50-2.74$ & 1,237 & $15.2 \%$ & 36 & $30.9 \%$ & $2.8 \%$ \\
\hline $2.75-2.99$ & 1,990 & $29.5 \%$ & 42 & $48.1 \%$ & $2.1 \%$ \\
\hline $3.00-3.24$ & 2,849 & $49.9 \%$ & 52 & $69.5 \%$ & $1.8 \%$ \\
\hline $3.25-3.49$ & 3,105 & $72.2 \%$ & 40 & $86.0 \%$ & $1.3 \%$ \\
\hline $3.50-3.74$ & 2,574 & $90.7 \%$ & 28 & $97.5 \%$ & $1.1 \%$ \\
\hline 3.75 and above & 1,289 & $100.0 \%$ & 6 & $100.0 \%$ & $0.5 \%$ \\
\hline Total & 13,919 & & 243 & & $1.7 \%$ \\
\hline
\end{tabular}

Source: Barnes and Carr, supra note 45.

In his study, Sander proposes combining the LSAT and undergraduate GPA into a single weighted average, using weights that correspond roughly to those used in many law schools' admissions. ${ }^{64}$ We refer to this average as the "Sander Index." Because the units of this index are difficult to interpret, we convert it to a percentile score. This score ranges from 0 to 100 , and represents the percentage of law school matriculants with lower index scores. That is, a student with a percentile score of 75 has better academic credentials than three quarters of law school matriculants, but worse credentials than the remaining quarter. ${ }^{65}$

Figure 2.2 shows the fraction of applicants in each grid cell who are black, arrayed against the percentile score of the best-qualified student in the cell. Black applicants are heavily concentrated in the cells containing the lowest LSATs and GPAs, and are severely underrepresented among those corresponding to the best qualifications. By construction, the grid cells containing students with percentile scores above 50 encompass the most-qualified half of

${ }^{64}$ See Sander, Systemic Analysis, supra note 6, at 393.

${ }^{65}$ Because applicants with low LSAT scores and GPAs are unlikely to be admitted, the index distribution for applicants is below that of matriculants: At least $62 \%$ of applicants have percentile scores below 50, and at least $23 \%$ have percentile scores below 10 . 
all students who entered law school in 1991. With only one exception, every such cell has a black share of less than 3 percent. $^{66}$

\section{Figure 2.2: Black Share of Applicants in Each Grid Cell, By MAXimum Percentile SCORE INCLUDED IN CELL, 1990-1991}

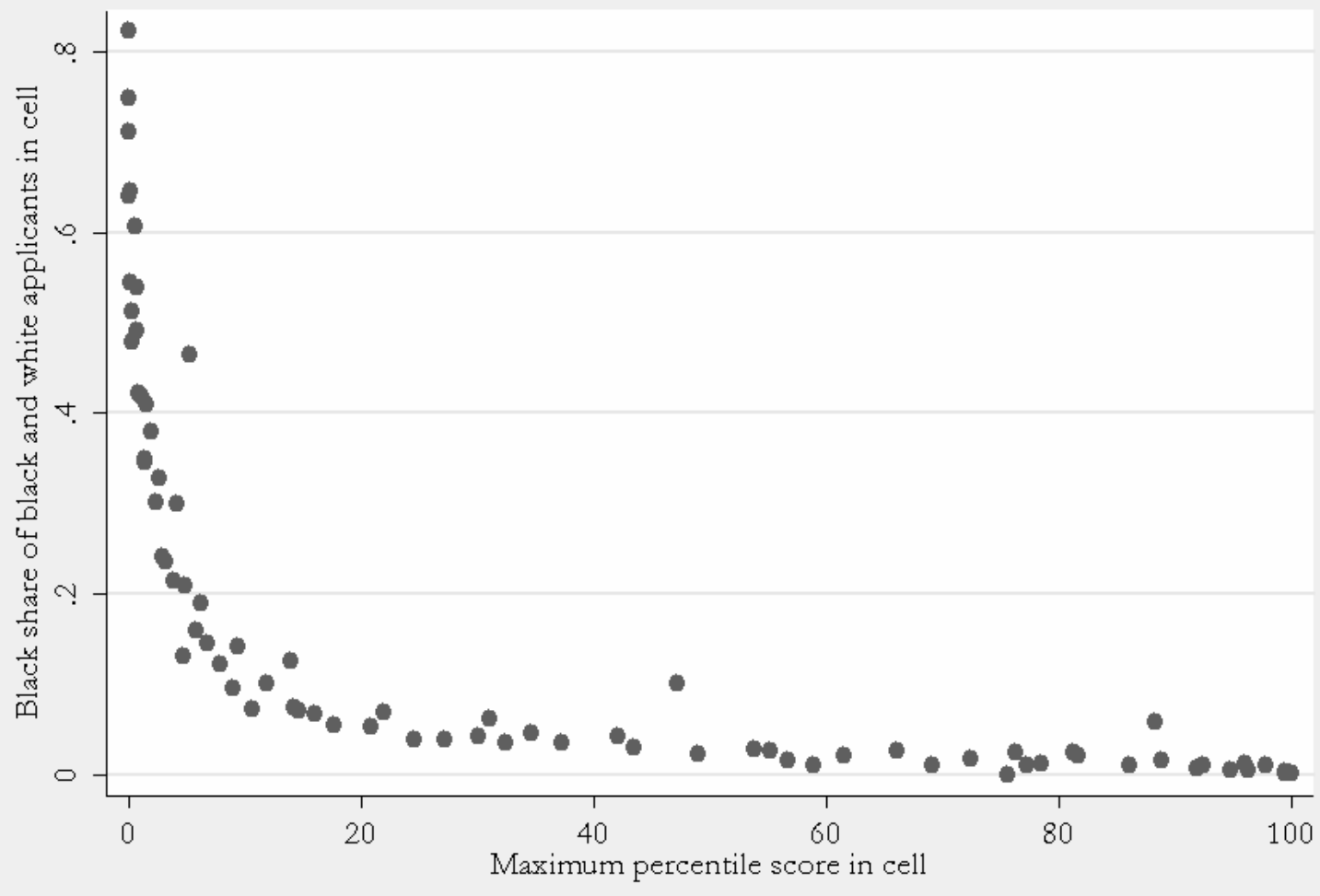

Source: Authors' analysis of grid and BPS data.

It is again instructive to consider the qualifications needed to gain admission to a selective law school. Yale Law School, consistently the law school with the lowest acceptance rate, ${ }^{67}$ reported to the LSAC the fraction of applicants who were admitted in each of 30 LSAT-GPA cells. $^{68}$ The only cells for which admissions rates exceeded 4 percent were those corresponding

\footnotetext{
${ }^{66}$ The sole exception is the cell containing applicants with LSAT scores of 46 and above but undergraduate GPAs of 2.5-2.75. There were only 87 applicants in this cell, as compared with 604 in the median cell.

${ }^{67}$ See Best Graduate Schools, published annually in The U.S. News \& World Report, dating back to 1990.

${ }^{68}$ See The Official Guide to U.S. Law Schools, 1992-1993, at 411.
} 
to GPAs of 3.5 and above and LSAT scores of 38 or higher. ${ }^{69}$ Black students comprised only 0.6 percent of law school applicants with credentials above these thresholds. Blacks are nearly as underrepresented in the ranges from which moderately-selective law schools draw their applicants. For example, at American University's Washington College of Law (ranked in “Quartile Two," ranks 45 through 88, in $1992^{70}$ ), 91 percent of admitted students in 1990-1991 had LSAT scores above 32 and GPAs above $25 .^{71}$ Only 2.2 percent of law school applicants with credentials above these thresholds were black.

Unfortunately, we do not have information about other aspects of students' applications. It is possible that black applicants have better unobserved credentials-recommendation letters, essays, etc. - than do white applicants with the same scores and grades. If so, the statistics presented here may overstate the gap in the number of academically qualified white and black applicants. They are unlikely to overstate it greatly, however, both because any black advantage on these unobserved dimensions is likely to be small ${ }^{72}$ and because the LSAT score and GPA are the strongest determinants of law school admissions.

\section{Who Is Admitted Where?}

Before beginning our analysis of the effect of affirmative action on black students' success rates, it is useful to describe admissions outcomes for black and white students as they are today. The grid data provide a first look at this. By comparing the number of applicants in each grid cell with the number of students who were admitted to at least one school and the number who

${ }^{69}$ Cell LSAT ranges are reported according to their percentile ranks. The cells in question have percentile ranks of 81 or above, which correspond approximately to a score of 38 . See Luebke, supra note 48.

${ }^{70}$ U.S. NEWS AND WORLD REPORT (Mar. 23, 1992), at 80.

${ }^{71}$ See The OfFICIAL GuIDE TO U.S. LAW SCHOOLS, 1992-1993, at 67.

72 If black students had better unobserved qualifications than white students with the same observed credentials, we should expect them to earn higher grades in law school than their observably-similar white classmates. Wightman finds that the opposite is the case. See Beyond FYA, supra note 37, at 21-22. This is a common result in analyses of undergraduate performance, see Jesse Rothstein, College Performance Predictions and the SAT, $121 \mathrm{~J}$. ECONOMETRICS 297-317 (2004). Of course, other factors - greater difficulty in social adjustment, greater participation in part-time employment or work-study, outright discrimination - may serve to depress black students' performance. 
matriculated, we can compute admission and matriculation rates. For example, in 1990-1991, 293 black students with LSAT scores between 26 and 29 and undergraduate GPAs between 2.75 and 2.99 applied to law schools. 191 students (65 percent) were admitted to at least one school, and 172 students (59 percent of applicants and 90 percent of admitted students) matriculated. ${ }^{73}$

Adding across all cells in the grid data, 7,312 black students applied to law schools in 1991, comprising 7.9 percent of the total applicant pool and 9.0 percent of black and white applicants. While 57 percent of white applicants were admitted to at least one school, only 47 percent of black applicants were. Admitted black students matriculated at a slightly higher average rate than admitted white students ( 85 percent vs. 79 percent), however. This may reflect different options: In the grid data, we know only that a student was admitted to at least one school, not the identity of the school or schools, and black students may be admitted to better or worse schools on average than are white students.

At each point in the distribution of credentials, black applicants were admitted at higher rates than whites. Thus, among applicants with LSAT scores of 26-29, 26 percent of whites and 61 percent of blacks were admitted to at least one school; for scores of 38-41, these figures were 81 and 94 percent, respectively. Students who were admitted and matriculate had stronger credentials than do those admitted students who did not matriculate, but the degree of selection on entering credentials was much smaller. ${ }^{74}$ The black-white gap in entering credentials was similar among matriculants as among admitted students.

Unfortunately, the grid data omit key pieces of information about the application process: We do not know how many applications a student submitted or to which schools, nor how many admissions offers she received. There is presumably important heterogeneity in each, accounting for some of the variation in outcomes: A student who submits only a single application to a highly selective school is much less likely to be categorized in the grid data as "admitted" than one with the same credentials who applies more broadly. ${ }^{75}$

\footnotetext{
${ }^{73}$ See Barnes and Carr, supra note 45.

${ }^{74}$ The average matriculant comes from a cell with mean percentile score equal to 49 . This figure is 38 for admitted non-matriculants and only 9 for applicants who were not admitted.

75 There are likely differences between black and white students in their typical application behavior. Black college applicants submit more applications to highly selective schools than do white students with the same SAT scores. See Alan Krueger et al., Race, Income and College in
} 
To partially fill the holes in our understanding left by the grid data, we turn to the BPS, with observations on individual law students. The BPS contains limited information about the application process - we know how many applications a student submitted and how many schools offered admission, but nothing about which schools were included in either set - and nothing about students who are not admitted to any law school or choose not to matriculate. Moreover, for confidentiality reasons, the BPS does not report the specific schools that students attend. Instead, 163 law schools are categorized into six "clusters": "Elite," "Public Ivy," "2 $2^{\text {nd }}$ Tier Public," " $2^{\text {nd }}$ Tier Private," “ 3 rd Tier," and "Minority," with the final category referring to historically black schools and others with high minority shares and, typically, very low selectivity. ${ }^{76}$ Despite these limitations, the BPS data can be used to summarize the end results of the application process, combining unobserved decisions about applications, admissions, and matriculation.

Table 2.2 lists the mean LSAT score, $25^{\text {th }}$ and $75^{\text {th }}$ percentile scores, and fraction black at schools in each of the six BPS clusters. The cluster labeled "minority" has, not surprisingly, a much larger black share than do the others; it also has by far the lowest test score distribution. Of the other five clusters, the Elite schools have the highest LSAT scores and the highest black shares; the two groups with the lowest LSAT scores also have the lowest black shares.

25 Years: The Legacy of of Separate and Unequal Schooling, 8 AMER. L. \& ECON. REV. 1 (2006). Chambers et al., supra note 8 at 1864, cite evidence that black law school applicants submit fewer applications than whites. Differences in application behavior will create spurious differences in admissions rates that do not reflect differences in admissions standards.

${ }^{76}$ The clusters are meant to group similar schools on a variety of dimensions, including selectivity, public/private control, minority share, etc. No such exercise can produce groups that are homogenous in each dimension, and the cluster labels are not always accurate. For example, perhaps $40 \%$ of the schools in the "Public Ivy" cluster are in fact private. See Wightman, LSAC National Longitudinal Bar Passage Study, supra note 50, at 8-9, for a description of the clusters. As we shall see, the "Minority" cluster differs in important ways from the other five. 
TABle 2.2: ChaRaCterizing THE SiX Clusters

\begin{tabular}{|c|c|c|c|c|}
\hline \multirow[b]{3}{*}{ Cluster } & \multicolumn{2}{|c|}{ LSAT } & \multicolumn{2}{|r|}{ Fraction black } \\
\hline & Mean & 25-75 range & Actual & $\begin{array}{c}\text { Among all matriculants in } \\
25-75 \text { range }\end{array}$ \\
\hline & (1) & (2) & (3) & (4) \\
\hline$\overline{\text { Elite }}$ & 41.9 & $39-45$ & $8.7 \%$ & $1.7 \%$ \\
\hline Public Ivy & 38.9 & $35.5-43$ & $7.9 \%$ & $2.3 \%$ \\
\hline 2nd tier public & 37.8 & $35-41$ & $8.5 \%$ & $2.8 \%$ \\
\hline 2nd tier private & 35.5 & $33-39$ & $5.2 \%$ & $3.8 \%$ \\
\hline 3rd tier & 32.5 & $30-35$ & $4.9 \%$ & $8.2 \%$ \\
\hline Minority & 28.7 & $24-33$ & $48.0 \%$ & $19.1 \%$ \\
\hline All law schools & 36.7 & $33-41$ & $8.0 \%$ & $3.4 \%$ \\
\hline
\end{tabular}

Source: BPS data.

The patterns emerging from Table 2.2 - particularly the positive correlation between the LSAT scores in a cluster and its black share-stand in sharp contrast to the extreme underrepresentation of black students among applicants with high LSAT scores. This table clearly indicates that race plays an important role in the allocation of admitted students to schools. To illustrate this, Column 4 shows the black share among all matriculants with LSAT scores within each cluster's 25-75 percentile LSAT range. That is, Column 4 describes the black enrollment share that we would see at each cluster if each school admitted and enrolled black and white students at random from those with LSAT scores in the range shown in Column 2. In the four most selective clusters, simulated black shares are much lower than are actually observed, indicating that the black enrollment share at these schools is substantially higher than it would be under race-blind admissions. The same is true for the least selective cluster, "Minority." By contrast, the $3^{\text {rd }}$ tier cluster, which draws from the lower portion of the applicant pool, would have higher black shares if relatively low-scoring black students were not disproportionately admitted to more selective schools.

Another way to express these patterns is to examine particular points in the distribution. Consider the cell containing LSAT scores between 38 and 41 and GPAs between 3.5 and 3.75. Students in this cell possess strong academic qualifications; their percentile scores for the Sander index range from 67 to 87 . There were 2,602 black and white applicants from this cell, of whom 1,917 matriculated. The BPS sample indicates that 10 percent of the white matriculants but 54 percent of the black matriculants from this cell enrolled at schools in the "Elite" cluster. This 
pattern is universal: At every point in the admissions index distribution, a larger fraction of black than white BPS respondents is enrolled at an "Elite" school.

We can bring the grid and BPS data together to summarize the distribution of admissions outcomes for white and black applicants with different admissions credentials. For simplicity, we collapse the six BPS clusters into two categories, highly selective (the Elite and Public Ivy clusters) and less selective (the remaining four clusters). ${ }^{77}$ There are four possible outcomes for each applicant: rejection at every school; admission to at least one law school but a decision not to matriculate; matriculation at a selective school; and matriculation at a less selective school.

Figure 2.3 shows the distribution of students at each percentile score across each of the four outcomes, separately for whites (Panel A) and blacks (Panel B). ${ }^{78}$

77 This is not the only sensible division; the " 2 nd Tier Public" cluster should perhaps be assigned to the same group as the "Public Ivy" cluster. Other divisions yield similar results.

${ }^{78}$ To create this graph, we compute the distribution of outcomes in each grid cell, then assign each the mean percentile score of BPS respondents in that cell. We smooth the data across cells for legibility. Details are available from the authors. Note that the number of applicants at each percentile score varies substantially with both the score and race, as indicated by Figure 2.2-there are few black applicants with high percentile scores and relatively few whites with low scores. 


\section{Figure 2.3: APPlication OUtComes, BY RACE AND ENTERING QUALIFICATIONS}

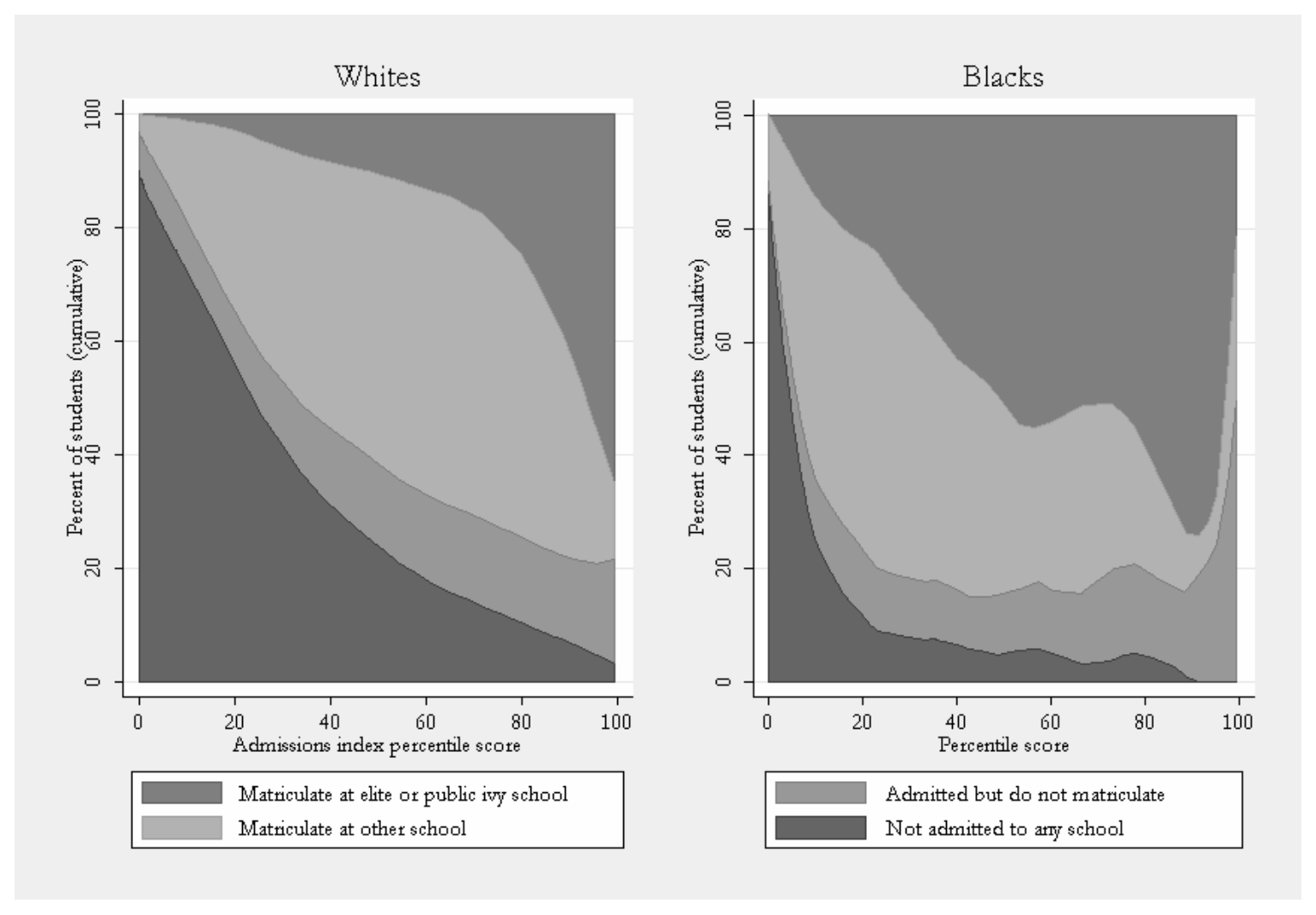

Source: Authors' analysis of grid and BPS data.

We can see that low scoring black applicants are much more likely to be admitted than are white applicants with the same credentials. This difference shrinks but does not vanish at higher scores. Matriculation rates for admitted white and black students are generally similar, with two exceptions: At the very bottom of the pool, nearly all admitted black students matriculate while a notable minority of admitted white students do not, and at the very top of the pool the black matriculation rate declines sharply. The latter effect is most likely noise, due to the very small number of black applicants with qualifications in this range; the former plausibly reflects preferences that provide black applicants better sets of schools to choose among than are available to whites with similar scores. Consistent with these findings, notably larger shares of black than white matriculants enroll at highly selective schools at nearly every point in the distribution.

Figure 2.4 gives yet another look at the distributions of admissions credentials and application outcomes for white and black students in 1990-1. Here, for each percentile score, we 
show the number of applicants of each race, the number of students who ultimately matriculated and the number who admitted at Elite and Public Ivy schools. This figure offers another illustration that there are very few black applicants with strong academic credentials. There were only 423 black applicants in 1991 with percentile scores above 40, a score that 30,059 white applicants exceeded, and only 275 black applicants with scores above 52, the median score for white matriculants. Nearly all of these students matriculate at elite schools.

\section{Figure 2.4: NuMber OF APPLiCANTS AND MATRICUlants, BY RACE AND ENTERING QUALIFICATIONS}
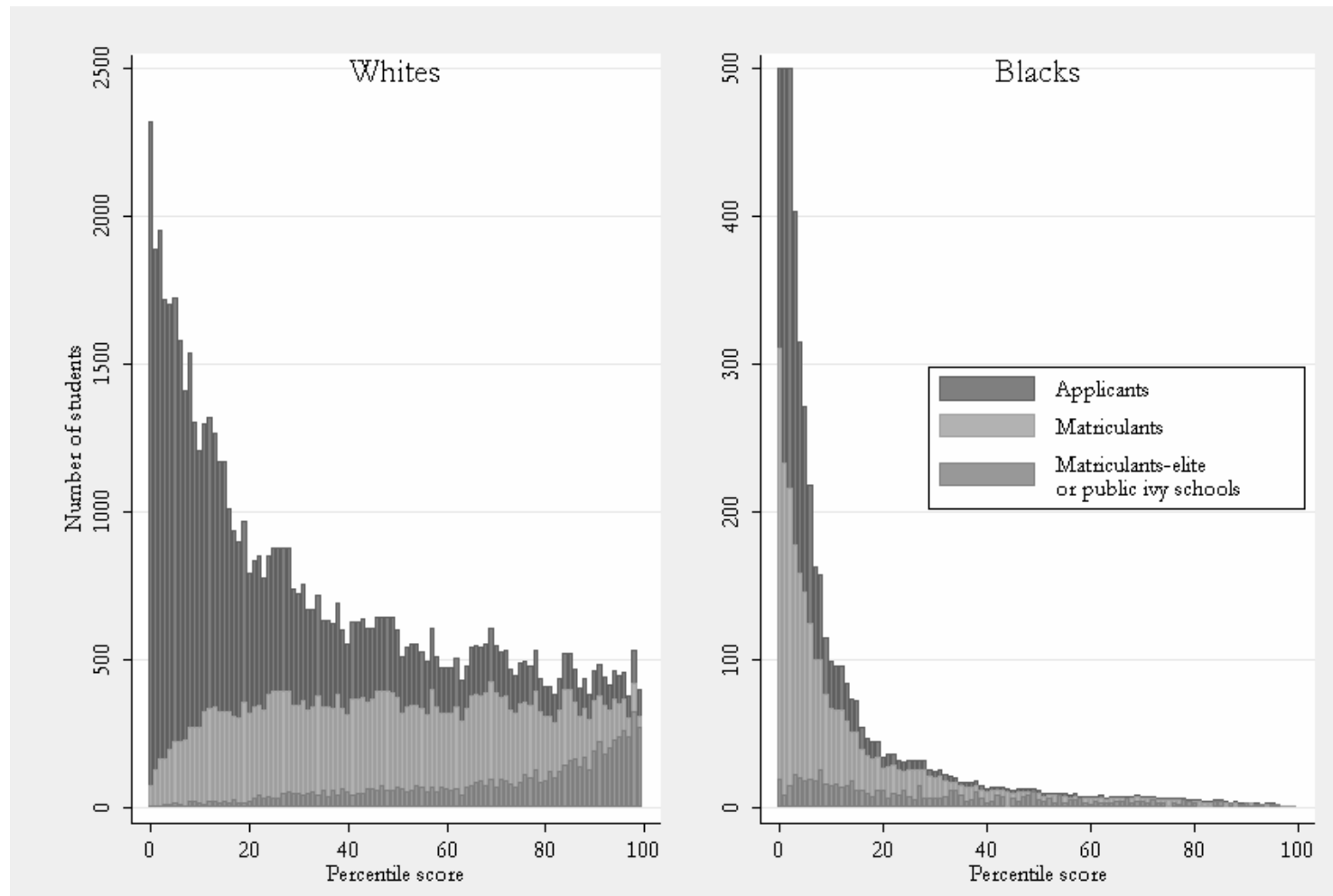

Source: Authors' analysis of grid and BPS data. Black applicants are censored at 500; there are not 1,500 but 4,147 black applicants with percentile scores of 3 or less.

\section{Cascade Effects}

Debates about admissions policy and the role of affirmative action occur in the shadow of large, persistent gaps in the credentials of applicants. The figures and tables in this section clearly reveal that admissions preferences are essential, given current applicants, to the 
maintenance of diversity in law schools, and that without sizable preferences the number of black students at selective law schools would fall to nearly zero.

Sander argues that the elimination of preferences would affect black enrollment only at the most selective schools. ${ }^{79}$ The remaining schools would benefit from a "cascade effect": Black students who, in the absence of racial preferences, would be admitted to second-tier schools are today snapped up by the top-tier schools, so that the second tier schools would not enroll any black students if they did not themselves use racial preferences to admit black students who would not otherwise meet their admissions standards. This, in turn, exhausts the supply of black students who would, in the absence of racial preference, attend third-tier schools, and the process cascades. By Sander's logic, if preferences were eliminated, each school would enroll a representative fraction of students from its slice of the "true" credentials distribution, leaving all but the most selective with approximately the same black representation that they have today.

Figure 2.4 provides reason for strong skepticism about this portion of Sander's argument. It is not just the most selective law schools that would have to settle for very low black shares in a race-blind admissions process. There were only 218 black applicants with percentile scores between 40 and 60 in 1991, for example, as compared with 11,547 white applicants. Even a school that admitted in a race-blind way from this range - the middle of the distribution - would wind up with a class that was less than two percent black. While the cascade effect is undoubtedly real, it appears that the sheer size of the black-white gap in entering qualifications would overwhelm it for all but the least selective schools. We return to this issue in Part V.

${ }^{79}$ Sander, Systemic Analysis, supra note 6, at 417. 


\section{Part III. Testing the Mismatch Hypothesis}

\section{A. What Is Not Evidence of Mismatch?}

Before discussing the strategies that researchers have used to estimate mismatch effects, we discuss several types of evidence that appear relevant but tell us little or nothing about the mismatch hypothesis.

First, it is incontrovertible that average outcomes for black law students are worse than those for white law students. 92 percent of white matriculants graduate from law school, but only 81 percent of black matriculants do so. 87 percent of white graduates and 64 percent of black graduates pass the bar exam within one year; 89 percent and 70 percent, respectively, pass within two years. From these facts alone it may be tempting to conclude that affirmative action is severely harming black students' probabilities of graduating from law school or passing the bar.

Black-white gaps in average outcomes do not support this conclusion, however. First, this comparison is between different subsets of potential white and black law students: We observe graduation rates only for those white applicants who are admitted to law school without the benefit of preferences, but the black graduation rate is an average of two groups: those black students who would have been admitted to law school under race-blind admissions and those who were admitted only through affirmative action. The latter group - we estimate in Part V that at least 63 percent of black law students in 1991 would not have enrolled without preferencesplausibly has lower graduation and bar passage rates than the former, depressing the black average relative to that which would be obtained from a group selected by the mechanism used to select white law students.

Even more important, there is no reason to think that average outcomes would be the same for black and white students selected by the same mechanism. Our estimates in Part V indicate that even the subset of black students who would attend law school without preferences would have mean LSAT and percentile scores 5.4 and 27 points, respectively, below the averages for white matriculants. If these entering credentials are at all predictive of future success - as has 
been exhaustively demonstrated - gaps in average outcomes would persist even with race-blind admissions. $^{80}$

A second uninformative comparison is between black and white students at a particular law school. ${ }^{81}$ As we show in Part V, black and white students in each cluster differ importantly in their entering academic credentials, and this certainly carries over to individual schools. Again, if entering credentials are predictive of success, it is unsurprising that success rates should be lower for black than for white students at a school. Elimination of affirmative action would shrink the gaps in entering credentials but by no means eliminate them.

More importantly, the effect of affirmative action on the gap in outcomes within a particular school does not measure mismatch, which has to do with effects on students rather than on schools. A simple example shows the importance of this distinction. Suppose that the actual school attended has no effects on student outcomes, so there are no mismatch effects. Consider School X that enrolls white students with LSAT scores of 42 but, because it and its competing schools give preferences, enrolls a selected group of black students with scores of 38 . If preferences were eliminated, the black students with LSATs of 38 would no longer be admitted to school X and would instead go to a less selective school Y. School X would replace them with a smaller number of black students with LSATs of 42, who previously attended the moreselective $\mathrm{Z}$ but are no longer admitted there. ${ }^{82}$ Average outcomes for black students at school X would likely rise, simply because a better-prepared group of students has replaced a less qualified group, and the black-white gap at school X would shrink. But by our assumption that schools do not matter, this shift would have no effect on any individual student's outcomes.

A third sort of evidence that might be thought to indicate mismatch concerns the performance of black students relative to white students with the same entering academic

${ }^{80}$ See, e.g., id., at 420.

${ }^{81} \mathrm{See}$, id. at 426 (noting that "the median black student got the same first-year grades as the fifth- or sixth-percentile white students. Only $8 \%$ of the black students placed in the top half of their classes").

${ }^{82}$ Note that in this example, the black-white gap in LSATs at school X disappears with raceblind admissions. This arises only because we assume that there is no variation in LSAT scores at school X; if X enrolled students with 42 s and $43 \mathrm{~s}$, a gap would remain because a higher fraction of blacks than whites with scores in this range have scores of 42 . We discuss this point more fully in Part V. 
credentials at the same schools. ${ }^{83}$ That is, by controlling for entering academic credentials, one might hope to take account of the "shifting students" problem - that the set of students enrolled at any individual school depends on the availability of preferences - which bedevils the withinschool comparison. Even with detailed controls, it will be difficult to form a valid comparison: If the credentials measures are incomplete, there are likely to be differences between the average unobserved characteristics of black and white students with the same observed academic credentials. But suppose that the researcher solves this problem: doing so by definition removes precisely the variation that could potentially indicate mismatch: With the exact same observed and unobserved credentials, black and white students at the same schools are equally academically mismatched, so any negative selectivity effects deriving from mismatch should apply to both equally.

As this discussion indicates, to properly identify mismatch effects one must focus solely on the causal effects of schools of different types on their students. It is particularly important to maintain the distinction between effects on schools and effects on students: As we have seen, even if there are no mismatch effects on students, affirmative action will tend to reduce the average outcomes of black students at individual schools.

\section{B. Credible Strategies for Estimating Mismatch}

Researchers have proposed several strategies that can identify the effects of selective schools on their students, under certain assumptions. A strategy amounts to a specification of an appropriate comparison group, one that tells us how the black students who are admitted to selective schools via affirmative action preferences would have performed in the absence of

\footnotetext{
${ }^{83}$ Analyses that attempt to take account of differences in college admissions regimes typically find evidence that black students have worse outcomes than do whites with the same credentials at the same schools. See, e.g., Thomas J. Kane, Racial and Ethnic Preferences in College Admissions, in THE BLACK-WHITE TEST SCORE GAP (Christopher Jencks and Meredith Phillips eds., 1998) ; William G. Bowen \& DereK BoK, The Shape OF THE River, 76-78, 383 (2000); Rothstein, supra note 72. Estimates for law schools are more mixed, but there is at least some evidence pointing in the same direction here. See Wightman \& Muller, supra note 15; Wightman, Beyond FYA, supra note 37; Anthony \& Liu, supra note 15. Note that the law school studies do not address the differences in admissions regimes applied to black and white students, so are not necessarily comparing similarly-selected groups from each race.
} 
these preferences. Identifying a valid comparison group poses considerable challenges, and each of the proposed strategies relies on a plausible - but ultimately untestable - assumption that the chosen comparison is valid.

\section{Selective-Unselective Comparisons}

The most straightforward comparison is between students of the same race and with the same admissions credentials who are observed attending schools of differing selectivity. ${ }^{84}$ If these students are assumed to be identical but for their choice of schools, it follows that the group attending less-selective schools serves as a valid counterfactual for those attending more selective schools.

We find this approach unpersuasive. As we have noted, the BPS - like most research data sets - lacks information about non-numerical aspects of students' applications. Law schools may consider essays and recommendations in making decisions; if so, these account for a portion of the variability in admissions outcomes even among students matched on race and on observed numerical qualifications. Consider, for example, law school applicants with LSAT scores between 30 and 33 and undergraduate GPAs between 3 and 3.25. Credentials in this range correspond to admissions indices in the bottom quarter of matriculants, so students in this group are typically underqualified for the most selective schools. In our 1992 law school applicant data, 11 percent of the black applicants in this cell were not admitted to any law school at all, while another 6 percent matriculated at schools in the "elite" cluster. Differences in admissions outcomes of this magnitude seem unlikely to be attributable to chance, and more likely to reflect unobserved differences between the two groups of students. These would violate the underlying assumption of the selective-unselective strategy, and bias the resulting estimates. Most likely, those students who are admitted to elite schools despite poor numerical credentials are strong on other dimensions, and would have done relatively well if they had attended less-selective schools. If so, the selective-unselective comparison will indicate an overly-positive effect of selective schools on their students, potentially masking true mismatch effects.

\footnotetext{
${ }^{84}$ Bowen and Bok, supra note 83, at 59-68, perform this sort of analysis for college students. See also Chambers et al., supra note 8, at 1884; Ayres \& Brooks, supra note 10, at 1819; Ho, supra note 10, at 109.
} 
Second-Choice Analyses

In their study of college applications, Stacy Berg Dale and Alan Krueger propose an innovative strategy to avoid this problem. They compare students attending highly selective schools with those who were admitted to those schools but elected to attend less-selective schools instead. The unobserved qualifications of students in the latter group are likely similar to those of the former group; after all, both were admitted to the highly selective school. ${ }^{85}$ While this comparison still relies on untestable assumptions - e.g., that a student's decision to attend a less-selective school is uninformative about her ambition or drive - the required assumptions are far more plausible than for the full selective-unselective comparison.

Ian Ayres and Richard Brooks use the BPS data to implement a strategy "similar in spirit" to Dale and Krueger's, but note important differences between the analyses. ${ }^{86}$ Sander also endorses this strategy, but minimizes important limitations of the BPS data that render the analysis unconvincing. ${ }^{87}$ Ayres and Brooks compare students attending their "first choice" schools with those who were admitted to their first choices but chose not to attend. They presume that students' first choices are more selective than the second choices, although the data do not identify the "first choice" school or its selectivity.

Moreover, there is good reason to suspect that the "second choice" students would have achieved worse outcomes than "first choice" students even if both attended the same schools, as

\footnotetext{
${ }^{85}$ See Stacy Dale \& Alan Krueger, Estimating the Payoff to Attending a More Selective College: An Application of Selection on Observables and Unobservables, 117 Q. J. ECON. 1491 (2002). Dale and Krueger are not concerned specifically with mismatch but more generally with the effect of selective schools on their students. They find that the effect of school selectivity on post-college wages is positive but small, and that it is larger for more disadvantaged students. This is the opposite of the pattern that mismatch effects would generate.

${ }^{86}$ See Ayres \& Brooks, supra note 10, at 1831.

${ }^{87}$ See Sander, Systemic Analysis, supra note 6, at 453 ("The most conclusive way [to test the mismatch hypothesis] would be an experiment comparing matched pairs of blacks admitted to multiple schools, with the 'experimental' black student attending the most elite school admitting them and the 'control' black student attending a significantly less elite school"). Dale and Krueger use this design only under an unusual use of the word "experiment": Students in the Dale and Krueger study are not randomly assigned to attend their most selective option or another one, but make their own choices between them. Dale and Krueger must assume that students choosing a more selective school do not differ systematically from those choosing less selective schools; a true randomized experiment would ensure this was so.
} 
the latter group appears to be wealthier, ${ }^{88}$ on average, and students from wealthier backgrounds typically do better in school than do those from less-well-off backgrounds. ${ }^{89}$ Absent better data than are currently available for law students, we conclude that the second choice strategy is not particularly informative. $^{90}$

\section{Black-White Comparisons}

A final strategy is to compare black students with white students with the same credentials, irrespective of the school that they attend. The availability of admissions preferences for black students means that they have the opportunity to attend much more selective schools than do whites with the same credentials. To the extent that this opportunity is harmful, we should expect to see depressed performance among black students relative to a comparison group of white students. The key assumption of this strategy is that the black sample would have posted the same performance as the white comparison group had the two been treated identically in admissions. Sander describes the strategy:

$[R]$ acial preferences for blacks have the effect of elevating them to much more elite schools, so that if we compare two students with similar credentials, one white and one black, the black student will usually be at a significantly more elite school than the white one, and the black student will usually have much lower credentials than most of his classmates.

The premise of the white-black comparison is that three things are true when we compare white law students with black law students: First, blacks tend to perform about the same in law school as do whites with similar entering credentials and are about as likely to graduate and pass the bar as are whites with similar grades from the same schools. Second, racial preferences tend to place blacks at much

\footnotetext{
${ }^{88}$ Only $21 \%$ of "first choice" students receive any grants, tuition reimbursement, or need-based scholarships during their 1L years, while 75\% of "second choice" students turned down their first choice school for lack of financial aid. This comes from our attempt to reproduce Ayres and Brooks" "second choice" sample in the BPS data. We have not reproduced their precise sample, though we believe we have come close. Ayres and Brooks discuss the limitations of their estimates at length, and note most of the issues discussed here. See Ayres \& Brooks, supra note 10 at 1832 (referring to differences "from the stronger design of Dale and Krueger's study"). ${ }^{89}$ See, e.g., Jesse Rothstein \& Cecilia Rouse, Constrained After College: Student Loans and Early Career Occupational Choices, unpublished manuscript, Princeton University (2007). ${ }^{90}$ In his Reply to Critics, supra note 30, at 1973, Sander argues for a different version of the second choice analysis. He compares Ayres and Brooks' second choicers with all other black law students. Their approach has none of the advantages of the Krueger and Dale comparison.
} 
more elite schools than whites with similar credentials, creating the "credentials gap" between blacks and their classmates. Third, this credentials gap causes blacks to get dramatically lower grades, on average, than do their white counterparts at less elite schools, and these low grades seriously undermine their chances of graduating and passing the bar. ${ }^{91}$ (Italics added)

We generally agree with Sander's characterization but differ on two points. Sander's first premise - that black students perform the same as white students with similar entering credentials - is an assumption about what would happen in a counterfactual world where black students do not receive preferences, not a statement about what we should observe in the data. In the actual world of affirmative action, the selection process that determines which students attend which schools is dramatically different for black and white students. Accordingly, this premise is unverifiable in the data. In particular, comparisons of outcomes of black and white students observed attending the same schools are uninformative.

Also, Sander's third "premise" is not a premise at all, but rather the conclusion of his analysis. Given the first two premises, the strategy would correctly estimate the mismatch effect even if it were zero, that is, if school selectivity did not depress students' grades or their chances of graduating or passing the bar.

We prefer the strategy of comparing black to white students over the other available alternatives, and indeed we rely on it in our analysis below, though it too has limitations. It implicitly attributes any black underperformance to mismatch. Because there are a variety of potential sources of black underperformance other than mismatch, ${ }^{92}$ this strategy will tend to indicate mismatch effects even if there are none, and if there are mismatch effects it will tend to indicate larger effects than are actually present.

\footnotetext{
${ }^{91}$ See Sander, Reply to Critics, supra note 30, at 1967.

92 In a variety of contexts black students have been found to "underperform" white students at the same schools even after differences in credentials and in selection are taken into account. See, for example, Rothstein, supra note 72. One explanation might be an unwelcoming law school culture. See Timothy T. Clydesdale, A Forked River Runs Through Law School: Toward Understanding Race, Gender, Age, and Related Gaps in Law School Performance and Bar Passage, 29 LAW \& SOC. INQUIRY 711 (2004). (writing that "minorities...confront stigmatization throughout legal education" and, at 761, that this "exacerbates the entering educational gaps of minority" law students); Susan Sturm and Lani Guinier, The Law School Matrix: Reforming Legal Education in a Culture of Competition and Conformity, VAND. L. REV. (forthcoming 2007) (on the culture of law school and its effects on women and people of color).
} 


\section{Implementing the Black-White Comparison}

Several important issues arise in implementing the black-white comparison. One is selection into the sample of law school matriculants: Comparisons of law school graduation rates between black and white law students exclude applicants who were unable to gain admission to any law school. As we have shown, many applicants fall into this category, but white applicants are much less likely to receive an admissions offer than black applicants with the same (observable) credentials. While one might be willing to assume that the average white law school applicant has comparable potential to an average black college graduate with the same LSAT score and undergraduate GPA, this is less plausible when the comparison is restricted to the 70 percent of black applicants and only 24 percent of white applicants who were admitted to at least one law school (as is seen, for example, among applicants with LSAT scores between 26 and 29 and GPAs between 3.25 and 3.49). One worries that the white students who were admitted had exceptionally strong recommendation letters, essays, or other application materials, while the admission criteria were lower for similarly-credentialed black students. If true, this will create a disparity in unobservables, producing spurious black underperformance that has nothing to do with mismatch. The problem is particularly severe for students with low LSAT scores and GPAs, as Figures 3.5 and 3.6 indicate that a great many white applicants like this are not admitted to any law school. Estimates of black-white gaps for students with poor numerical credentials should thus be taken with a grain of salt.

A second, more technical, issue concerns the specification of the statistical model. Recall the logic of the black-white comparison, and let us walk through the implications of this logic for a pair of college roommates, one white and one black, with identical admissions credentials. On average, the black student will be admitted to more selective schools than her roommate. Where her white roommate will have credentials that resemble those of her new classmates, the black student - if she chooses to attend a selective school - will be in a more rarified pool and will be relatively less prepared. This may depress her performance during her first year. Even if it does not, simply because the competition is stiffer we may presume that she will attain a lower first year class rank than does her old roommate. If the mismatch hypothesis holds, the black student will struggle during law school and learn less than does her less-overmatched white college roommate, possibly dropping out or failing the bar exam. 
Sander implements the black-white comparison by modeling each step of this process. ${ }^{93}$ First, he studies the degree of preferences given to black students, estimating the difference in "eliteness" between the schools that similarly-credentialed black and white students attend. ${ }^{94}$ Label this difference as "W"schools that similarly-credentialed white students attend. Second, he estimates the effect of the law school's eliteness on the grades earned during law school: Each unit of eliteness lowers a student's grades by " $\mathrm{X}$ ". 95 Third, he estimates the simultaneous effects of eliteness ("Y") and the law school GPA ("Z") on outcomes like graduation, bar passage, and quality of the first job. ${ }^{96}$ The net effect of attending an elite school on these outcomes is $\mathrm{Y}+\mathrm{X}^{*} \mathrm{Z}$, where the first term $(\mathrm{Y})$ is the direct effect of eliteness and the second term $\left(\mathrm{X}^{*} \mathrm{Z}\right)$ is the indirect effect operating through eliteness' effect on the GPA. Because black students attend schools that are W units more elite than white students, and because race is assumed to have no effect other than that operating through the eliteness of the school attended, the black-white difference in outcomes is $\mathrm{W}^{*}(\mathrm{Y}+\mathrm{X} * \mathrm{Z})$.

Given the serious limitations of the available data, we believe that the three-step strategy will likely produce misleading results. To identify the mismatch effect of affirmative action, Sander must correctly estimate four effects from three different statistical models. If any of these models goes wrong, the answer obtained at the end of the process will be biased. This imposes extreme demands on the data. ${ }^{97}$ In particular, direct estimation of $\mathrm{X}, \mathrm{Y}$, and $\mathrm{Z}$ requires good measures of the eliteness of the school attended and of law school grades. The BPS "cluster"

93 See Richard H. Sander, Mismeasuring the Mismatch: A Response to Ho, 114 YALE L. J. 2005, 2008.

${ }^{94}$ Sander, Systemic Analysis, supra note 6, at 416.

${ }^{95}$ See id. at 425.

96 See id. at at 439, 444, and 458.

${ }^{97}$ Another issue is that the three-step model cannot easily incorporate nonlinearity or heterogeneity of selectivity effects. Sander now argues that there is a "curvilinear" effect of grades in the third step: Bar exam success rates are more sensitive to small changes in grades for students with very low grades than for those with higher grades. See Sander, Reply to Critics, supra note 30, at 1969-71. More importantly, the mismatch hypothesis is by definition one about heterogeneous effects of selectivity: A student with a 22 LSAT score might be mismatched at an elite law school, but one with a 42 LSAT would not be; the effect of eliteness on the former student would be much different than that on the latter. To our knowledge, no one - including Sander - has attempted to implement the three-step model while taking account of these complexities. 
variable does not measure with any precision the eliteness of the school attended, ${ }^{98}$ and the BPS law school GPA measure, by design, prevents comparisons across schools. ${ }^{99}$ These limitations make it impossible to accurately estimate the intermediate steps of the three-step model, and make the resulting estimates of the net effect of being black unreliable.

Ho notes that it is unnecessary to distinguish between the direct and indirect effects of selectivity (i.e. between $\mathrm{Y}$ and $\mathrm{X}^{*} \mathrm{Z}$ in the notation above). ${ }^{100}$ He estimates the total effect of eliteness on outcomes in one step, without attempting to distinguish between direct and indirect channels. We believe this approach will also likely yield inaccurate estimates. Like Sander, Ho requires that school selectivity be well measured. Both Ho's and Sander's estimates are also subject to the criticisms outlined above of selective-unselective comparisons: If students attending selective schools are systematically different in their abilities or motivations from students attending less selective schools, both authors will misidentify the effect of school selectivity, and therefore that of mismatch. ${ }^{101}$

In our view, the most compelling way to implement the black-white comparison is to do it in a single step, sidestepping the intermediate effects of race on selectivity, selectivity on grades, and selectivity and grades on longer-run outcomes. We regard it as well established fact - see our analysis in Part II-that black students attend more selective schools than do whites with the same credentials. If mismatch effects are important, then black students should experience worse average outcomes than similarly-qualified white students. This difference can be estimated directly, as the "reduced form" effect of race on outcomes. This specification should control for differences in academic credentials, ideally in a flexible way that allows for nonlinearities in the relationship between, say, the LSAT score and the graduation rate. It should not, however, control for the law school attended nor the grades earned in law school, as these are both intermediate effects of the student's race.

${ }^{98}$ Sander notes in his Reply to Critics that he had not (at the time of writing his initial analysis) appreciated the crudeness of the BPS "clusters," which overlap substantially in the selectivity of the schools they include. See Sander, A Reply to Critics, supra note 30, at 1972-73.

${ }^{99}$ See Jesse Rothstein and Albert H. Yoon, Mismatch in Law School, Princeton Education Research Section Working Paper \#16 (June 2006), at 17.

${ }^{100}$ Ho, supra note 10, at 105.

${ }^{101}$ Ho attempts to reduce selection bias by controlling for a wide variety of student characteristics that are not included in Sander's analysis, but this may not fully solve the problem. See Ho, supra note 10, at 105. 
This strategy thus has the substantial advantage that it does not require good measures of either school quality or law school grades. If there are mismatch effects to be found in the full threestep structural model, they should appear as black-white differences in the reduced-form specification. ${ }^{102}$ As noted earlier, this strategy is not specific - many factors other than mismatch effects could produce black-white gaps in bar passage rates and other outcomes. These will tend to bias the black-white comparison - however implemented - toward overstating the importance of mismatch effects. Our estimates should therefore be seen as an upper bound to the possible magnitude of mismatch.

\section{Part IV. Black- White Gaps in Law School Outcomes, Holding Credentials Constant}

In this Part, we present estimates of the difference in mean outcomes between black and white students with the same entering credentials, which we have argued provides a credible upper bound to any mismatch effects on black students' outcomes. We consider several categories of outcomes: performance in law school, bar exam performance, and post-law-school employment. From the first category, we examine the student's class rank at the end of the first year of law school and the student's graduation status as of five years after law school matriculation. From the second, we examine whether the student was ever observed to take the bar exam, whether she passed the exam on the first attempt, and whether she ever passed the exam. ${ }^{103}$ Our employment outcomes are measured from the BPS's follow-up survey, administered four to six months after students' graduation. We examine the fraction of students who have jobs that appear to be relatively prestigious, ${ }^{104}$ the fraction working at large private

${ }^{102}$ Our earlier work explores the technical details of this one-step strategy, and readers are referred to it for a more involved discussion. See Rothstein and Yoon, supra note 99.

${ }^{103}$ There are several limitations to the BPS bar exam measures. Most importantly, we do not observe the state in which the exam was taken nor the actual score; we simply observe whether the student passed on the first attempt and whether she ever passed (by July of the $5^{\text {th }}$ year after beginning law school).

${ }^{104}$ We code the following job types as prestigious, and refer to them as "good jobs": Judicial clerkships, large private law firms (50 or more attorneys), academic, prosecutor's office, and public defender's office. We code the remaining job types - mid-size and small firms, solo 
law firms, and the reported annual salary. Following standard practice, we focus on the natural $\log$ of the annual salary. The black-white gap in this can be interpreted as the percentage difference between black and white students' salaries.

The vast majority of entering law students graduate within three years and pass the bar exam shortly thereafter. These measures are thus insensitive to performance differences among students who clear a fairly low threshold. Still, if mismatch effects are preventing many black students from having the opportunity to practice law, we should see effects on these margins. Our remaining outcomes - particularly our analyses of prestigious and large firm jobs — are more sensitive to performance at the higher end. ${ }^{105}$

We begin with graphical evidence. ${ }^{106}$ Figure 4.1 shows average first year class rank as a function of the entering percentile score, separately for white and black students. The class rank is scaled to equal zero for the lowest-ranked student at each law school and one for the highestranked student. It is thus measured only relative to other students at the same law school; by design, there is no difference in average class rank between students at the most and least selective law schools.

practice, government agencies, public interest, and other-as non-prestigious. Those who have not yet accepted a job are counted as not having good jobs.

${ }^{105}$ Employers of young lawyers may themselves practice affirmative action, hiring black students with low achievement over white students with higher achievement. If so, the blackwhite gap in employment outcomes will not be reflective of the gap in academic performance. ${ }^{106}$ These graphs are drawn from the analysis reported in Rothstein and Yoon, supra note 99, who describe the details of their construction. 


\section{Figure 4.1: Mean First-Year Class Rank, by Race and Percentile Score}

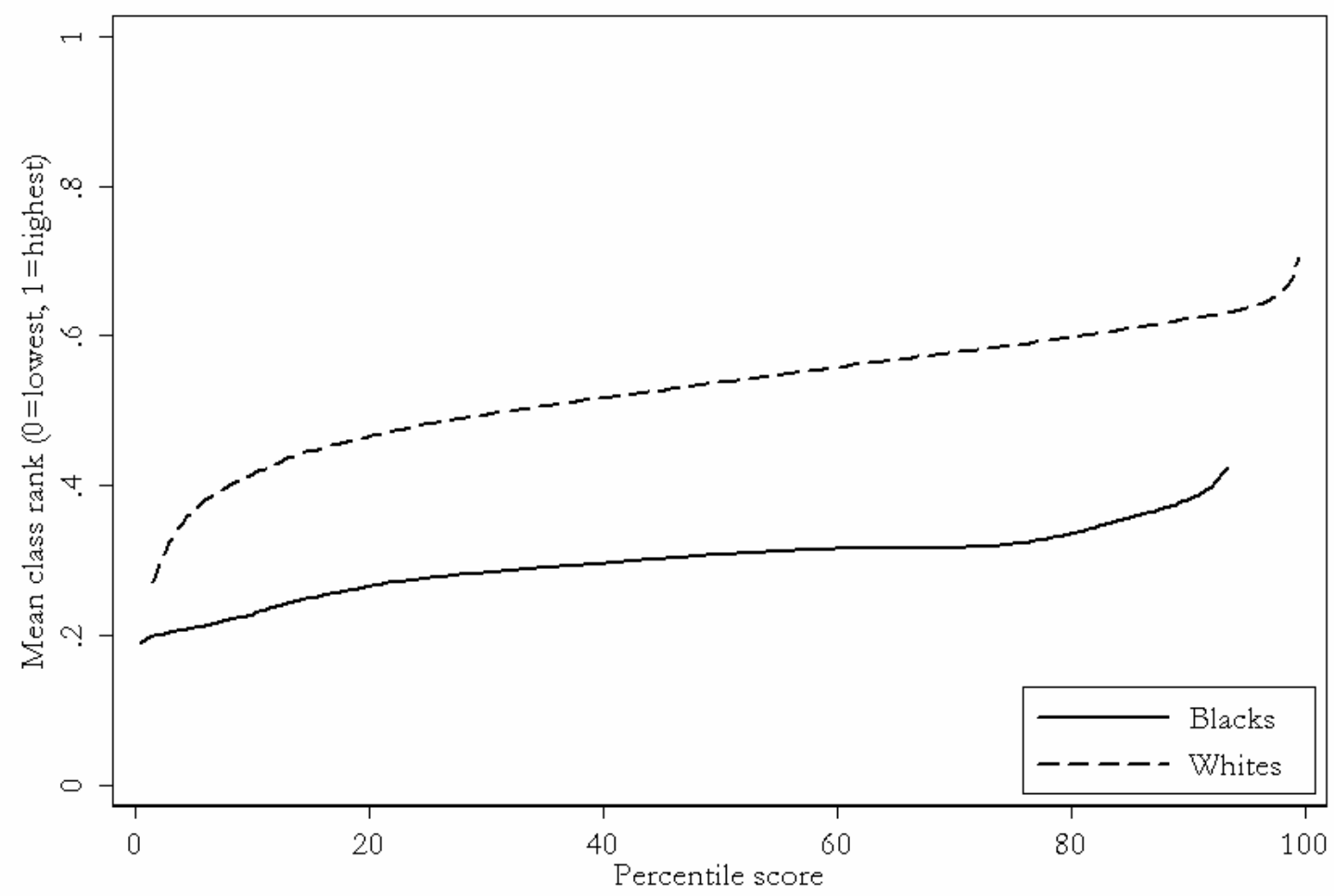

Source: Authors' analysis of BPS data.

Figure 4.1 shows that within each race the relationship between student credentials and class rank is positive, but fairly weak except among the most- and least-qualified students. ${ }^{107}$ At any fixed level of entering credentials, there are large differences between the average class ranks of black and white students. Among students with percentile scores of 20, for example, the average white student's first year GPA places her at the $47^{\text {th }}$ percentile of her class, while the average black student winds up at only the $26^{\text {th }}$ percentile of her (potentially different) class. The gap is slightly larger among students with better credentials, reaching a maximum around the $75^{\text {th }}$ percentile.

${ }^{107}$ This weak relationship most likely reflects a negative effect of school selectivity on class rank, holding individual credentials constant: More selective schools offer stiffer competition for the top ranks, and most likely assign lower ranks to any given achievement level. Because students with better credentials will tend to attend more selective schools, on average, this masks the positive relationship between credentials and student achievement. 
This black-white gap in class rank combines two effects. First, black students, because they attend more selective schools on average than do white students with the same credentials, face stiffer competition and will rank lower within their schools. Second, if mismatch effects were important, black students may suffer from them, and may underachieve as a result. ${ }^{108}$ The first effect lowers only relative performance, and would therefore disappear with an absolute scale. By contrast, the second effect impacts absolute performance levels.

A strategy for separating these effects must focus on outcomes measured on absolute scales. Law school grades are inappropriate, both because grading standards - the achievement level required for any given grade - differ across schools and because the BPS data suppress any between-school differences in grade point averages.

Law school graduation is a superior measure (though perhaps not perfectly so, as schools may differ in their willingness to graduate struggling students). Figure 4.2 presents law school graduation rates, again as functions of the percentile score and separately for black and white matriculants. If mismatch effects are important, we should expect that black students would graduate at lower rates than do whites with the same entering credentials. This does not jump out of the graph: Graduation rates are high throughout the credentials distribution, and except at the lowest percentile scores black students graduate at approximately the same rate as whites. Among the students with the lowest percentile scores -58 percent of black students and 6 percent of white students in law school have percentile scores below 10 - the gap is larger, approaching twenty percentage points.

\footnotetext{
${ }^{108}$ There is a third potential contributor to this gap, of course: Black students may underperform white students with the same credentials even in the absence of mismatch effects, particularly if the credentials do not fully capture differences in student preparedness or if law school is a hostile environment for black students.
} 
Figure 4.2: Graduation Rates, by Race And Percentile Score

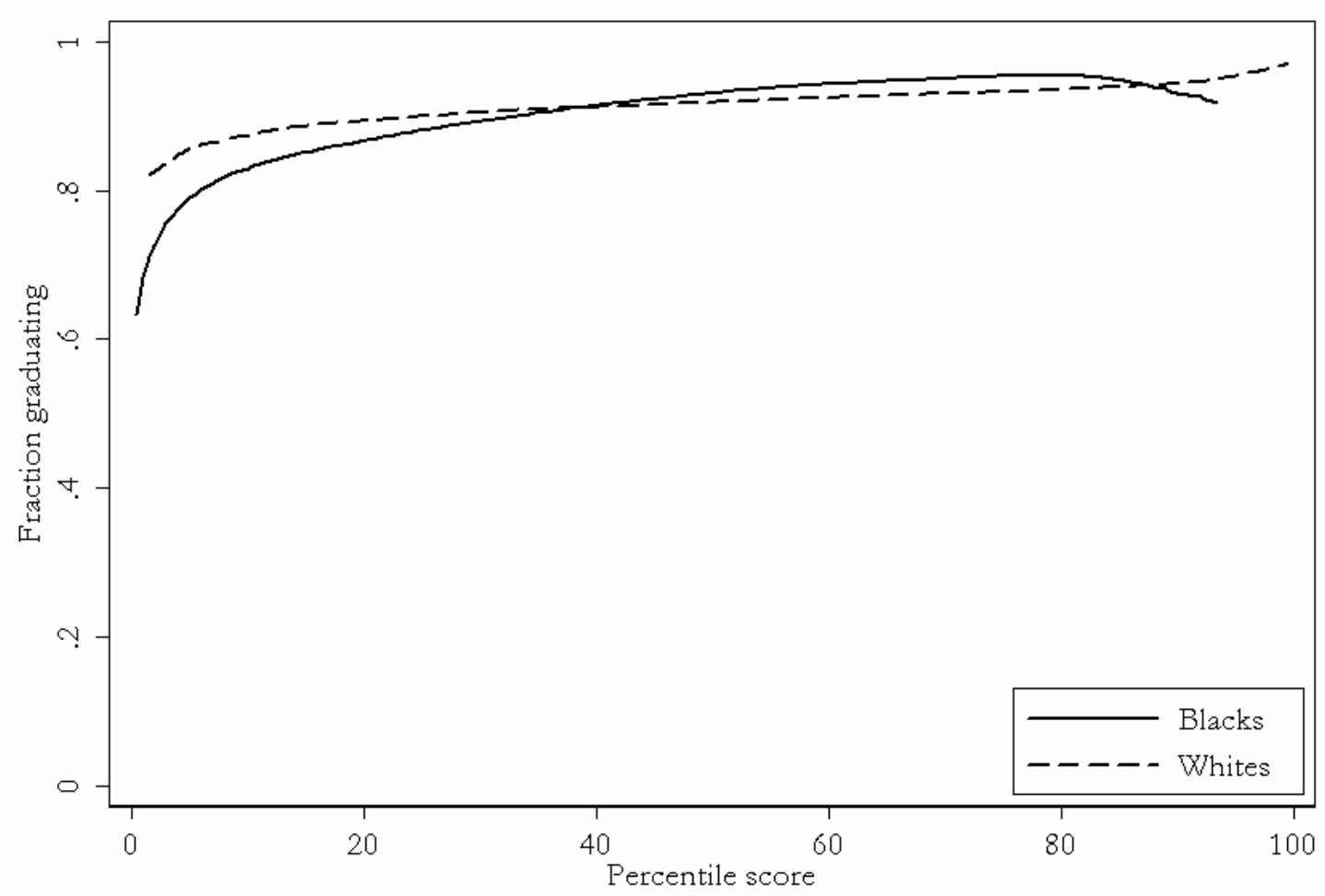

Source: Authors' analysis of BPS data.

Our final graphs examine bar exam outcomes. ${ }^{109}$ Figure 4.3 reports the fraction of students who passed the bar exam on the first attempt. ${ }^{110}$ Approximately 92 percent of white students and 62 percent of black students pass their first bar exams. This largely reflects differences in entering credentials, as bar passage is strongly related to the percentile score even within race. Even when we compare students with the same percentile scores, however, we see important gaps in bar passage rates. These are relatively small through most of the distribution - about 8 percentage points for students with percentile scores around 40-but are larger -above 20 percentage points—among students with the weakest credentials.

${ }^{109}$ Bar passage is admittedly a blunt measure of performance - we observe whether a student passed or failed, but not her actual score. One advantage is that the bar exams are graded blind, without reference to the student's credentials, race, or school attended. The only threat to the comparability of bar exam outcomes is that the difficulty of the exam varies across states. Unfortunately, the BPS does not report the state in which the exam was taken, so we cannot control for this.

${ }^{110}$ Students who did not graduate or who did not attempt the exam are excluded. We examine exam-taking as a separate outcome below. 
Figure 4.3: Fraction of Graduates Passing the Bar Exam on the First Attempt, by RACE AND PERCENTILE SCORE

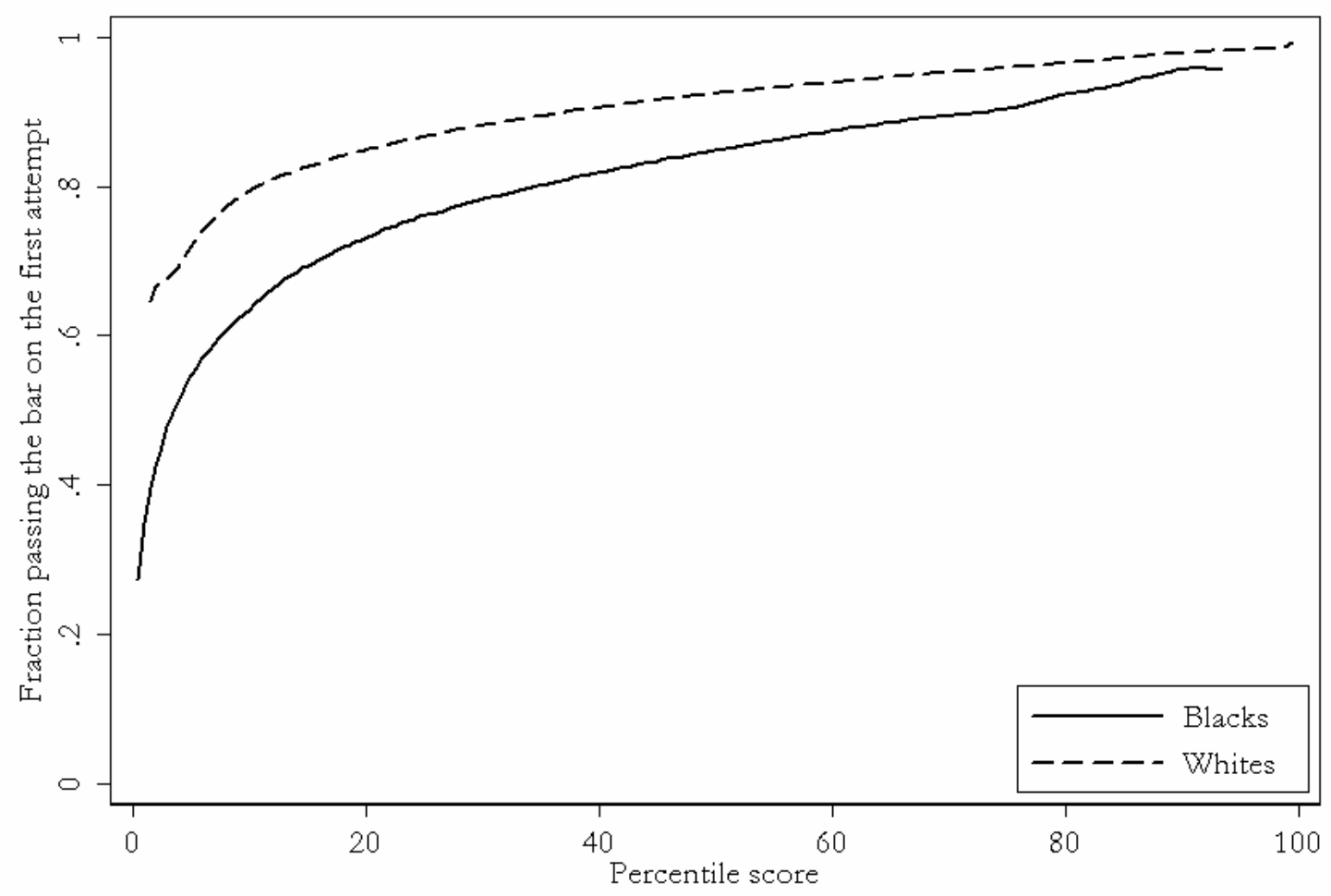

Source: Authors' analysis of BPS data.

Students who fail the bar exam may re-take it, and just over half of the students who failed the exam on the first attempt eventually passed. Figure 4.4 shows estimates of the fraction of graduates who ever passed the exam, restricted to those who attempted the exam at least once. Much of the black-white gap disappears when we focus on ultimate passage. We still see small gaps (around 5 percentage points at the $20^{\text {th }}$ percentile) through most of the distribution, however, and larger gaps among students with the poorest academic credentials. 
Figure 4.4: Fraction of Graduates Passing the Bar EXam by End of BPS SurVey, by RACE AND PERCENTILE SCORE

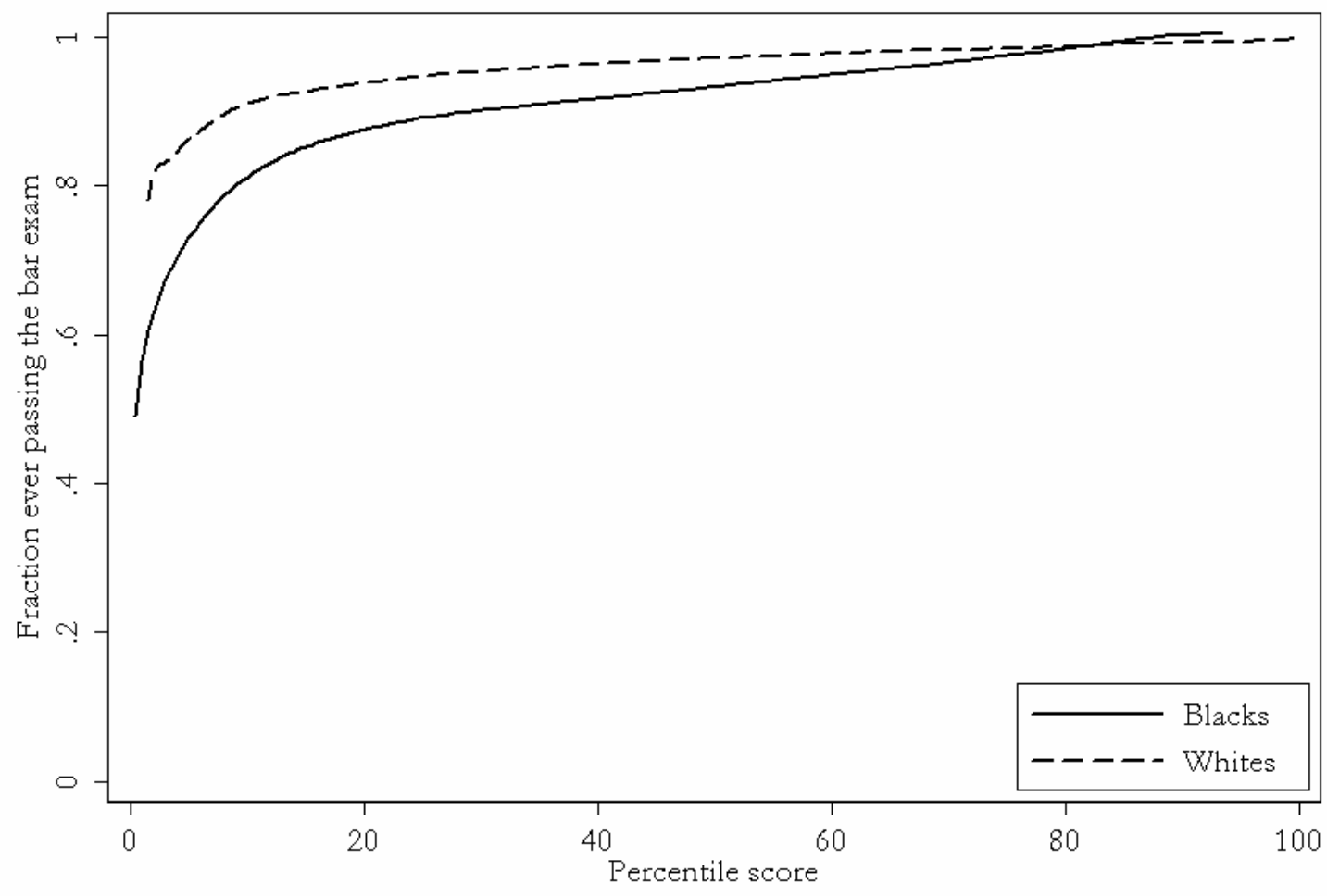

Source: Authors' analysis of BPS data.

Viewed together, Figures 4.1 through 4.4 offer mixed evidence for the mismatch hypothesis. Despite large black-white gaps in class rank - indicating that black students face much tougher competition than white students with the same LSATs and undergraduate GPAs - black and white graduation and bar passage rates are substantially similar, particularly among students with percentile scores above about 20. Below this threshold - recall that three quarters of black law school matriculants have percentile scores below 20 -we see larger gaps in outcomes.

Table 4.1 assembles the data from these graphs into estimates of mean black underperformance. The first column shows the raw black-white gap among all matriculants. Black students' class ranks are 30 percentage points lower than those of whites, on average. Black students graduate from law school at lower rates than white students; those who do graduate are (slightly) less likely to attempt the bar exam; and those who attempt the bar exam are much less likely to pass. Employment outcomes, in the last rows, are more ambiguous: Black law graduates are more likely to have good jobs after graduation (though these are slightly 
less likely to be at large private law firms - the "good jobs" effect is driven primarily by government jobs). Mean annual salaries are nearly 6 percent lower for black graduates than for whites.

Table 4.1: Black-White Gap in Outcomes, Holding Entering Credentials Fixed

\begin{tabular}{lcc}
\hline \hline & Raw & $\begin{array}{c}\text { Adjusted for differences in } \\
\text { entering credentials }\end{array}$ \\
\cline { 2 - 3 } & $(\mathbf{1 )}$ & $\mathbf{( 2 )}$ \\
\hline Class rank (0=lowest, 1=highest) & $-\mathbf{0 . 3 0}$ & $-\mathbf{0 . 1 6}$ \\
Graduation & $(0.01)$ & $(0.01)$ \\
& $-\mathbf{1 1 . 0 \%}$ & $-6.4 \%$ \\
Attempt bar (if graduate) & $(1.0)$ & $(1.4)$ \\
& $-\mathbf{2 . 1 \%}$ & $-1.1 \%$ \\
Pass bar on 1st try & $(0.8)$ & $(1.4)$ \\
& $-\mathbf{2 9 . 1 \%}$ & $-\mathbf{1 4 . 5 \%}$ \\
Pass bar ever (if attempt) & $(1.4)$ & $(2.1)$ \\
Good job & $-\mathbf{1 8 . 3 \%}$ & $\mathbf{- 9 . 3 \%}$ \\
& $(1.2)$ & $(2.0)$ \\
Large law firm job & $\mathbf{+ 4 . 1 \%}$ & $\mathbf{+ 1 2 . 8 \%}$ \\
log(annual salary) & $(1.9)$ & $(4.4)$ \\
& $-0.3 \%$ & $\mathbf{+ 8 . 2 \%}$ \\
\hline \hline
\end{tabular}

Source: Authors' analysis of BPS data. For column 2, we regress each outcome on a quartic in the admissions index, using only white students, and predict the outcomes the average white student would have if the white admissions index distribution matched that of blacks. Standard errors are in parentheses; bold coefficients are significant at the 5\% level.

Column 2 of the table shows the portion of these gaps that remains after we account for differences between black and white students' entering credentials. ${ }^{111}$ This comparison is more favorable to black students on every dimension. Black-white gaps in class rank, graduation, and

${ }^{111}$ Rothstein and Yoon, supra note 99, at 15 discuss a "reweighting" strategy for accomplishing this while allowing for arbitrarily nonlinear effects of entering credentials on outcomes. That strategy requires dropping from the analysis over ten percent of black students for whom there are too few white comparison observations. In order to retain all students in the present analysis, we adopt a less sophisticated approach. We regress each outcome on a quartic in the admissions index, using a sample of white students, and use the fitted values to predict the outcome that each black student would get if the white credentials-outcome relationship applied. Column 2 reports the difference between the observed average black outcome and the average of these predicted values. This is generally quite similar to that obtained from the more sophisticated reweighting approach. 
bar passage are each cut by about one half relative to the unconditional gaps in Column 1, though most remain statistically significant. The black graduation rate is 6.4 percentage points lower than that for white students with the same credentials. Among students who graduate, black and white students attempt the bar at approximately the same rates. The gap in first-time passage rates is 14.5 percentage points; for ultimate passage (among students who attempt the exam) it is 9.3 .

Employment outcomes show a substantially different pattern. Black students are 12.8 percentage points more likely to have first jobs that we classify as "good" than white students with the same credentials, and are 8.2 percentage points more likely to work at large law firms (those with more than 50 attorneys). Black students also earn slightly (about 5.6 percent) higher salaries than whites with the same credentials, though this gap is not statistically significant.

Taken together, the estimates in Table 4.1 are consistent with the presence of moderate mismatch effects on law school graduation and, even more so, on bar passage, though as noted previously the black underperformance identified here might have other roots. Table 4.1 disproves, however, the claim that the net effect of preferences in admissions and hiring is to hurt the employment outcomes of black law graduates, at least in the first years of their careers.

Figures 4.1-4.4 indicate that black-white gaps in outcomes vary importantly with student credentials. In Table 4.2, we disaggregate the gaps from Column 2 of Table 4.1, estimating them separately for each of five groups of students: Those with percentile scores below 10, between 10 and 20, between 20 and 40, between 40 and 60, and above 60. The first rows of the table show the number and percentage of black students in each range, while the remaining rows show black-white gaps, adjusted for differences in entering credentials, within each range. 
Table 4.2: Adjusted Black-White Gap in Outcomes, by Percentile Score

\begin{tabular}{|c|c|c|c|c|c|}
\hline & \multicolumn{5}{|c|}{ Admissions index percentile } \\
\hline & $\begin{array}{c}0-10 \\
(1)\end{array}$ & $\begin{array}{c}10-20 \\
(2)\end{array}$ & $\begin{array}{c}20-40 \\
(3)\end{array}$ & $\begin{array}{c}40-60 \\
(4)\end{array}$ & $\begin{array}{c}60-100 \\
(5)\end{array}$ \\
\hline \multicolumn{6}{|c|}{ Distribution of black students across categories } \\
\hline Number & 1,684 & 481 & 416 & 174 & 172 \\
\hline Percent of total & $58 \%$ & $16 \%$ & $14 \%$ & $6 \%$ & $6 \%$ \\
\hline \multicolumn{6}{|l|}{ Black-white gaps in outcomes } \\
\hline Class rank ( $0=$ lowest, $1=$ highest $)$ & $\begin{array}{l}-0.13 \\
(0.01)\end{array}$ & $\begin{array}{l}-0.20 \\
(0.01)\end{array}$ & $\begin{array}{l}-0.22 \\
(0.01)\end{array}$ & $\begin{array}{l}-0.23 \\
(0.02)\end{array}$ & $\begin{array}{l}-0.23 \\
(0.03)\end{array}$ \\
\hline Graduation & $\begin{array}{c}-9.4 \% \\
(2.0)\end{array}$ & $\begin{array}{c}-2.5 \% \\
(1.3)\end{array}$ & $\begin{array}{c}-0.7 \% \\
(1.2)\end{array}$ & $\begin{array}{c}+0.8 \% \\
(1.5)\end{array}$ & $\begin{array}{c}+1.4 \% \\
(2.3)\end{array}$ \\
\hline Attempt bar (if graduate) & $\begin{array}{c}-2.0 \% \\
(2.0)\end{array}$ & $\begin{array}{c}-0.8 \% \\
(1.1)\end{array}$ & $\begin{array}{c}+0.8 \% \\
(1.1)\end{array}$ & $\begin{array}{c}+1.9 \% \\
(1.4)\end{array}$ & $\begin{array}{c}-1.0 \% \\
(3.0)\end{array}$ \\
\hline Pass bar on 1st try & $\begin{array}{c}-17.5 \% \\
(3.1)\end{array}$ & $\begin{array}{c}-13.2 \% \\
(1.9)\end{array}$ & $\begin{array}{c}-9.9 \% \\
(1.8)\end{array}$ & $\begin{array}{c}-6.7 \% \\
(2.3)\end{array}$ & $\begin{array}{c}-4.8 \% \\
(2.8)\end{array}$ \\
\hline Pass bar ever (if attempt) & $\begin{array}{c}-12.1 \% \\
(2.9)\end{array}$ & $\begin{array}{c}-7.6 \% \\
(1.6)\end{array}$ & $\begin{array}{c}-4.8 \% \\
(1.3)\end{array}$ & $\begin{array}{c}-2.6 \% \\
(1.6)\end{array}$ & $\begin{array}{c}-1.1 \% \\
(1.4)\end{array}$ \\
\hline Good job & $\begin{array}{c}+6.0 \% \\
(6.4)\end{array}$ & $\begin{array}{c}+15.0 \% \\
(2.9)\end{array}$ & $\begin{array}{c}+22.8 \% \\
(2.9)\end{array}$ & $\begin{array}{c}+29.0 \% \\
(4.0)\end{array}$ & $\begin{array}{c}+32.8 \% \\
(5.0)\end{array}$ \\
\hline Large law firm job & $\begin{array}{c}+2.7 \% \\
(4.5)\end{array}$ & $\begin{array}{c}+10.1 \% \\
(1.8)\end{array}$ & $\begin{array}{c}+16.5 \% \\
(2.4)\end{array}$ & $\begin{array}{c}+20.3 \% \\
(3.6)\end{array}$ & $\begin{array}{c}+19.5 \% \\
(6.2)\end{array}$ \\
\hline log(annual salary) & $\begin{array}{l}-0.025 \\
(0.130)\end{array}$ & $\begin{array}{l}+\mathbf{+ 0 . 1 0 0} \\
(0.045) \\
\end{array}$ & $\begin{array}{r}+0.184 \\
(0.038) \\
\end{array}$ & $\begin{array}{l}\mathbf{+ 0 . 2 0 8} \\
(0.046) \\
\end{array}$ & $\begin{array}{l}\mathbf{+ 0 . 1 5 5} \\
(0.059) \\
\end{array}$ \\
\hline
\end{tabular}

Source: Authors' analysis of BPS data. Standard errors in parentheses. Bold coefficients are significant at the 5\% level. See Table 4.1 (column 2) for description of methods.

Consistent with Figure 4.1, the black-white gap in class rank is approximately constant across the five groups, and is, if anything, largest among students with the highest credentials. For the other outcome measures, however, the pattern is different. In each case, black students in the bottom decile of the admissions index distribution perform worse, relative to white students with the same credentials, than do those in higher deciles. Black underperformance in graduation and bar passage is far greater in the bottom decile than in the upper four quintiles of the admissions index distribution. Similarly, black graduates show substantially better employment outcomes than white graduates in the upper nine deciles, while gaps in the bottom decile are smaller and statistically insignificant.

This negative relationship between entering credentials and the size of the black-white gap in outcomes is important for two reasons. First, it suggests that we must exercise caution in inferring mismatch. Recall from Part II that the majority of white applicants with percentile 
scores below 20 (i.e. in the bottom two deciles) are not admitted to any law school. It is likely that these would-be students would have graduated and passed the bar exam at lower rates than those seen among admitted white students with the same credentials. If so, the comparisons between black and white law school matriculants, as in Tables 4.1 and 4.2, may be biased in favor of whites, particularly in the bottom percentile score ranges. That is, even if black and white applicants would have achieved similar average outcomes, there is reason to expect that those white students who actually matriculated would have outperformed the average black applicant even in the absence of affirmative action. Table 4.2 shows that the evidence for mismatch effects comes disproportionately from the subset of law students for whom this selection bias is most likely to be a problem. Absent a strategy for assessing its magnitude, conclusions about the size of the mismatch effect on the average black student cannot be very strong, and the estimates in Table 4.1 should be seen as upper bounds.

Second, the differences in the black-white gap across the credentials distribution are informative about how much the elimination of affirmative action could contribute to the closing of blackwhite gaps. In Part V we demonstrate that the number of black students admitted to law school would fall dramatically were race-based preferences eliminated. Under the (speculative) hypothesis that mismatch effects would disappear entirely with the elimination of preferences, it might be hoped that improved success rates of those black students who would be admitted would offset the reduction in admitted students, producing only small reductions or even increases in the number of black law graduates or bar entrants. However, we also show in Part V that nearly 80 percent of black students with percentile scores below 10 would not have had the opportunity to attend law school at all without the benefit of admission preferences. It is precisely these students whose success rates might be expected to improve if mismatch effects were eliminated, but of course students who do not attend law school are guaranteed not to succeed at it.

Thus, Table 4.2 indicates that, even we attribute all black underperformance to mismatch, eliminating racial preferences would do little to improve the performance of the black students who would remain. The black students admitted under race-blind rules would come disproportionately (relative to current black matriculants) from the upper end of the index distribution, where black-white gaps in outcomes are relatively small. Even if these gaps could 
somehow be made to disappear, this would have relatively little effect on the number of black graduates or bar-passers. By contrast, only a small fraction of the black applicants with percentile scores below 10 would be admitted without preferences. Accordingly, even if the success rate could be improved substantially for black matriculants in this range, the effect would be dwarfed by the reduction in the number of admitted students.

\section{Part V. The Effect of Affirmative Action on Law School Admissions Outcomes}

In this Part, we step back from our analysis of mismatch to examine the impact of affirmative action on admissions outcomes themselves, attempting to quantify the role that preferences play in generating the distribution of admissions outcomes described in Part II. To do so, we simulate the distribution of outcomes that would arise under race blind admissions, assuming that in the absence of preferences black applicants would have the same admissions outcomes as white applicants with the same LSAT scores and undergraduate GPAs. Similar methods have been used by to examine undergraduate admissions by Krueger et al. ${ }^{112}$

Our analysis indicates that affirmative action is responsible for nearly all of the diversity currently seen in the law student population generally, and at every law school of even moderate selectivity. As we showed in Part II, black students are dramatically underrepresented among law school applicants with moderate to strong academic credentials. As a result, fewer than half as many black students would be admitted to law school under race-blind admissions as are currently admitted. Many of those who would be admitted would be pushed several steps down the selectivity rankings, and some would choose other careers. The number of beginning black law students would fall by over 60 percent. The impact on selective law schools would be even more dramatic: The number of black students enrolling at the most selective group of law schools would fall by over 90 percent, to a trivial level: with race-blind admissions, less than one

112 See Krueger et al., supra note 75. Our analysis also resembles the "grid model" estimated by Linda Wightman in Threat to Diversity, supra note 15 and The Consequences of Race-Blindness: Revisiting Prediction Models with Current Law School Data, 53 J. LEGAL EdUC. 229 (2003) (hereafter referred to as Revisiting), and by FrANKLIN R. EVANS, APPLICATIONS AND ADMISSIONS TO ABA ACCREDITED LAw SchOOls: An ANALYSIS OF NATIONAL DATA FOR THE Class ENTERING IN THE CLASS OF 1976, at 40. 
percent of students at these schools would be black. The impact would be slightly smaller at lower-ranked schools, but would be substantial at all but the least selective, "3 3 rd tier" cluster. ${ }^{113}$

\section{A. Simulating Race-Blind Admissions: Methodology}

We assume that with race-blind admissions, black and white applicants with the same numeric, academic credentials would be admitted at the same rates. We recognize that law schools rely on other measures of ability beyond what we observe. There is substantial variation in admissions outcomes among students with the same observed credentials, presumably because some students have strong unobserved qualifications - essays, recommendations, etc. - while others do not. We do not assume that this heterogeneity would disappear with race-blind admissions. Instead, we assume that the distribution of admissions outcomes for black students would match that of white students with the same credentials - the same fractions of black and white applicants would be admitted to selective schools, admitted only to unselective schools, and not admitted at all.

Implicitly, then, we assume that black students' unobserved credentials have the same distribution as those of white students, and that observed differences in their admissions outcomes reflect the availability of preferences for black students. This assumption is also implicit in our analysis of mismatch in Part V, as it is only reasonable to assume that black and white students would achieve the same law school outcomes if they have similar average entering credentials. As before, we believe that it is most likely overly optimistic: Just as black students have lower average GPAs than white students with the same LSAT scores, it seems likely that when we match black students and white students on the basis of both LSATs and GPAs, the black students' other qualifications will be worse, on average, than those of the white students. ${ }^{114}$ If our assumption is indeed incorrect, we will overstate black admissions outcomes under race-blind admissions by assuming that they would match those of whites with the same observed qualifications, and accordingly we will understate the role of affirmative action.

\footnotetext{
${ }^{113}$ Our method is poorly suited to the analysis of historically black law schools. See the discussion in footnote 118 .

${ }^{114}$ This arises from the well-known statistical phenomenon of "regression to the mean." See Sir Francis Galton, Regression Toward Mediocrity in Hereditary Stature, 15 J. OF THE ANTHROPOLOGICAL InSTITUTE OF GREAT BRITAIN AND IRELAND 246 (1886).
} 
We make another important simplifying assumption: the admissions standards applied to white students' applications will not change with the elimination of affirmative action. This is almost certainly incorrect. Without preferences, some admissions slots currently given to black students would become available to white students who currently fall just short of admission. Still, the number of admission slots freed through the elimination of preferences would be small and the change in the white admissions standard would therefore be negligible. ${ }^{115}$

An important issue is that applicants' decisions whether to apply to law school, how many applications to submit (and to which schools), and, if admitted, whether to matriculate might all be affected by their perceived admissions probabilities. In a similar study of college admissions, Krueger et al. find that black high school students with moderately high SAT scores are much more likely to apply to the most selective colleges than are white students with the same SAT scores. ${ }^{116}$ They argue that this gap is probably due to the availability of affirmative action, and that black students' application behavior would likely resemble that of whites if the two groups of students faced equal admissions probabilities.

We follow Krueger et al. in assuming that application and matriculation behavior would converge with race-blind admissions. We do not, however, assume convergence in every dimension: we assume that reduced admissions probabilities will not dissuade any black students from applying to law school in the first place. This assumption is admittedly unrealistic. As we demonstrate below, many of today's applicants would not be admitted anywhere under race-blind rules. Many potential applicants would anticipate low probabilities of acceptance and forego applying to law school altogether. ${ }^{117}$ Because a fraction of these discouraged applicants would be admitted if they did apply, our assumption will lead us to overstate the number of black students who would be admitted, particularly at low qualifications levels.

115 Tom Kane makes an analogy to handicapped parking spaces. "Suppose that one parking space in front of a popular restaurant is reserved for disabled drivers. Many of the nondisabled drivers who pass by the space ... may be tempted to think that they would have an easier time finding a space if the space had not been reserved .... [T] he cumulative cost perceived by each passing driver is likely to exceed the true cost. . " Misconceptions, supra note 9, at 453. 116 See Krueger et al, supra note 75.

${ }^{117}$ An additional factor is that the low black shares at many law schools would likely make the environment appear more hostile to potential black applicants than it does today, perhaps dissuading many who would otherwise apply. See Chambers et al., supra note 8, at 1862. 
Taken together, we believe that our assumptions are reasonable, appropriately cautious, and conservative. Likely violations would lead us to understate the impact of eliminating affirmative action on diversity.

\section{B. What Would Race-Blind Admissions Look Like? Simulation Results}

The first step of our simulation is to model the overall law school student pool, without regard to the specific school attended, under counterfactual rules. We use the grid data for this.

\section{Table 5.1: Grid Model Simulation of the Impact of Eliminating Preferences on BLACK REPRESENTATION IN LAW SCHOOL}

\begin{tabular}{|c|c|c|c|c|}
\hline & \multirow{2}{*}{$\begin{array}{c}\text { Actual 1990- } \\
1991 \text { data } \\
\text { (1) }\end{array}$} & \multirow{2}{*}{$\begin{array}{c}\begin{array}{c}\text { With race-blind } \\
\text { admissions }\end{array} \\
(2)\end{array}$} & \multicolumn{2}{|c|}{ Effect of eliminating preferences } \\
\hline & & & $\begin{array}{c}\text { On \# enrolled } \\
\text { (3) }\end{array}$ & $\begin{array}{c}\text { As } \% \text { of current } \\
\text { (4) }\end{array}$ \\
\hline \multicolumn{5}{|c|}{ Number of black students } \\
\hline Applicants & 7,312 & 7,312 & -- & -- \\
\hline Admitted students & 3,429 & 1,615 & $-1,814$ & $-53 \%$ \\
\hline Matriculants & 2,928 & 1,077 & $-1,851$ & $-63 \%$ \\
\hline \multicolumn{5}{|c|}{ Black share of black and white matriculants } \\
\hline Applicants & $9.0 \%$ & $9.0 \%$ & -- & \\
\hline Admitted students & $7.5 \%$ & $3.7 \%$ & $-3.8 \%$ & \\
\hline Matriculants & $8.0 \%$ & $3.1 \%$ & $-4.9 \%$ & \\
\hline
\end{tabular}

Source: Authors' analysis of grid data.

The first column of Table 5.1 shows observed outcomes in the 1990-1991 cohort. 7,312 black students applied to law school. Of these, 3,429 were admitted to at least one school and 2,928 matriculated. Black students represented 9.0 percent of black and white applicants, 7.5 percent of admitted students, and 8.0 percent of matriculants. The second column shows what would happen if black admissions and enrollment rates came to resemble those of white students in the same grid cells. The number of black students admitted to at least one school would fall to 1,615, down 53 percent (column 4) from the status quo, and the black share among admitted students would fall to 3.8 percent. The number of black matriculants would fall even more precipitously to 1,077 . Only 3.1 percent of (black and white) law students would be black. 
The 1,077 black students who would enroll under race-blind admissions would be distributed across schools quite differently than are the 2,928 who actually enrolled. Figure 2.3 indicates that even among matriculants, black students are more likely to enroll at schools in the most selective clusters than are white students with the same credentials. Our grid model simulation thus shows the black share at these clusters falling by even more than does the overall black share. Table 5.2 presents the estimated black share at each cluster under status quo (Column 1) and race-blind (Column 2) admissions.

TAble 5.2: Grid Model Simulation of Black Representation in VARious Clusters

\begin{tabular}{|c|c|c|c|c|}
\hline & \multirow{2}{*}{$\begin{array}{c}\text { Actual 1990- } \\
1991 \text { data } \\
(1)\end{array}$} & \multirow{2}{*}{$\begin{array}{c}\begin{array}{c}\text { With race-blind } \\
\text { admissions }\end{array} \\
(2) \\
\end{array}$} & \multicolumn{2}{|c|}{ Effect of eliminating preferences } \\
\hline & & & $\frac{\text { On \# enrolled }}{(3)}$ & $\begin{array}{c}\text { As } \% \text { of current } \\
\text { (4) }\end{array}$ \\
\hline \multicolumn{5}{|l|}{ Number of students } \\
\hline All schools & 2,928 & 1,077 & $-1,851$ & $-63 \%$ \\
\hline Elite & 242 & 24 & -218 & $-90 \%$ \\
\hline Public Ivy & 460 & 103 & -357 & $-78 \%$ \\
\hline 2nd Tier Public & 842 & 196 & -646 & $-77 \%$ \\
\hline 2nd Tier Private & 698 & 473 & -225 & $-32 \%$ \\
\hline 3rd Tier & 165 & 196 & 31 & $19 \%$ \\
\hline Minority & 521 & 85 & -436 & $-84 \%$ \\
\hline \multicolumn{5}{|c|}{ Black share of black and white matriculants } \\
\hline All schools & $8.0 \%$ & $3.1 \%$ & $-4.9 \%$ & \\
\hline Elite & $8.7 \%$ & $0.9 \%$ & $-7.7 \%$ & \\
\hline Public Ivy & $7.9 \%$ & $1.9 \%$ & $-6.0 \%$ & \\
\hline 2nd Tier Public & $8.5 \%$ & $2.1 \%$ & $-6.4 \%$ & \\
\hline 2nd Tier Private & $5.2 \%$ & $3.6 \%$ & $-1.6 \%$ & \\
\hline 3rd Tier & $4.9 \%$ & $5.7 \%$ & $0.8 \%$ & \\
\hline Minority & $48.0 \%$ & $13.0 \%$ & $-35.0 \%$ & \\
\hline
\end{tabular}

Source: Authors' analysis of BPS and grid data.

Elimination of affirmative action would decimate black enrollment at the most elite cluster: Only 24 black students would enroll at the 16 schools in this cluster, 90 percent fewer than are seen there now and representing less than 1 percent of total (black and white) enrollment in the cluster. The "Public Ivy" and " 2 nd Tier Public" clusters would lose more than three quarters of their black students, and would wind up with black shares around $2 \%$ of total enrollment. Even the " 2 nd Tier Private" cluster would see its black enrollment decline by a third. Only the " 3 rd 
tier" cluster would see an increase in black enrollment, and this effect would be small in comparison. $^{118}$

Our simulation of admissions under race-blind rules thus indicates that affirmative action preferences are responsible for much of the observed representation of black students in law school, particularly at the most selective schools. Were these preferences eliminated, the number of black students beginning law school would fall by nearly two thirds. The three most selective clusters - enrolling 51 percent of law students - would see their collective black enrollment fall by 79 percent and their black share fall from 8.3 to 1.9 percent. ${ }^{119}$

\section{Mismatch and Race-Based Preferences}

Even with race-blind admissions the black-white gap in entering credentials within law schools would not disappear. This is a simple fact about statistical distributions, and reflects two characteristics of the law school admissions process. First, the distribution of credentials is lower for black applicants than for whites, and second, no law school enrolls a purely

${ }^{118}$ Our estimates indicate that black enrollment in the "Minority" cluster would fall 84\%. Recall that we have assumed that black students will, with race-blind admissions, have the same propensity to enroll in this cluster as do white students with the same credentials. This is a particularly poor assumption for this cluster, which seems to include several historically black law schools. Black students may be more likely to prefer these schools over more selective alternatives than are white students. A more realistic simulation that incorporated this effect would indicate higher black enrollment at the "minority" cluster under the race-blind admissions, primarily at the expense of the more selective clusters. Thus, our inability to incorporate black preferences for historically black law schools likely leads us to overstate black enrollment at each of the other clusters in our simulation.

119 This aligns with the expert testimony of Stephen Raudenbush on the consequences of eliminating affirmation action at the University of Michigan:

[I]n the year 2000 only 46 underrepresented minority applicants would have been admitted [with race-blind admissions] (instead of 170 who actually were admitted), of whom only 16 would enroll (instead of 58 who actually enrolled). Under this scenario, underrepresented minority students would have constituted $4 \%$ of the entering class in 2000 , instead of $14.5 \%$ as actually occurred. [Internal citations omitted]

Testimony of Stephen W. Raudenbush, Grutter v. Bollinger, 137 F. Supp. 2d 821, 840 (E.D. Mich. 2001). 
homogenous class of students. ${ }^{120}$ So long as there is any variation in credentials within each school, the average black student who falls within a school's range will have lower credentials than the average white student, at least on the numerical dimensions that we consider here. ${ }^{121}$

Consider a hypothetical school that enrolls only students with LSAT scores between 38 and 41 and GPAs between 3.0 and 3.24. Even in this narrow range, there are differences between the qualifications of black and white students: The average LSAT score of black students lags that of white students by 0.07 and the GPA gap is 0.004 . A more heterogeneous school would show even larger gaps. A school that enrolls a random sample of students with LSATs above 38 and GPAs above 3.0 will have black-white LSAT and GPA gaps of 1.7 and 0.14 , respectively. We should thus expect that sizable racial gaps in entering students' qualifications will persist even with race-blind admissions.

Table 5.3 shows several measures of black mismatch in each of the six BPS clusters, both in the observed data and in our race-blind simulation. Columns 3 and 4, for example, show blackwhite gaps in LSAT scores. Among students in the elite cluster, the mean black LSAT score trails that of the mean white by 6.8 points. The gap shrinks by more than half in our simulation, to 3.0 points, but does not disappear. ${ }^{122}$ Gaps are even larger in the other clusters, and all persist at fairly high levels in the race-blind simulation. Columns 5 and 6 repeat this calculation for the percentile score constructed from the LSAT and undergraduate GPA. Gaps are larger here as well, 18 points in the Elite cluster. They would decline with the elimination of affirmative action, but would remain at about half their current level in five of the six clusters.

${ }^{120}$ Even Yale, at which most admitted students in 1990-1991 had LSAT scores above 44, admitted 12 students with LSATs below 38. OfFICIAL GUIDE TO U.S. LAw SCHOOLS, 1992-93, at 411.

${ }^{121}$ See Chambers et al., supra note 8, at 1874 (noting that "Even if law schools adopted strictly 'race-neutral' admissions criteria...African American applicants and admittees would, on average, have lower LSATs and UGPAs than the white applicants and admittees")

${ }^{122}$ By way of comparison, the standard deviation of LSAT scores among white BPS respondents is about 5 points. The black-white gap within the elite cluster is therefore 1.3 standard deviations; this would shrink to 0.6 standard deviations with race-blind admissions. 


\section{TABle 5.3: BLACK-WHite GAPS In AdMissions QUALIFICATIONS, ACTUAL AND IN RACE-BLIND Simulation}

\begin{tabular}{|c|c|c|c|c|c|c|c|c|}
\hline & \multirow{3}{*}{\multicolumn{2}{|c|}{$\begin{array}{l}\begin{array}{c}\text { Number of black } \\
\text { students }\end{array} \\
\text { Actual Simulated } \\
\end{array}$}} & \multicolumn{4}{|c|}{ Black-white gaps } & \multirow{2}{*}{\multicolumn{2}{|c|}{$\begin{array}{c}\text { Avg. black } \\
\text { student's rank }\end{array}$}} \\
\hline & & & \multirow{2}{*}{\multicolumn{2}{|c|}{$\frac{\text { LSAT score }}{\text { Actual Simulated }}$}} & \multicolumn{2}{|c|}{ Percentile score } & & \\
\hline & & & & & Actual & Simulated & Actual & Simulated \\
\hline & (1) & (2) & (3) & (4) & (5) & (6) & (7) & (8) \\
\hline All matriculants & 2,928 & 1,077 & -8.1 & -5.4 & -37 & -27 & $16 \%$ & $27 \%$ \\
\hline By cluster & & & & & & & & \\
\hline Elite & 242 & 24 & -6.8 & -3.0 & -41 & -18 & $14 \%$ & $26 \%$ \\
\hline Public Ivy & 460 & 103 & -7.5 & -4.4 & -40 & -24 & $16 \%$ & $26 \%$ \\
\hline 2nd Tier Public & 842 & 196 & -8.9 & -4.4 & -48 & -23 & $10 \%$ & $28 \%$ \\
\hline 2nd Tier Private & 698 & 473 & -8.1 & -4.0 & -32 & -19 & $11 \%$ & $27 \%$ \\
\hline 3rd Tier & 165 & 196 & -8.2 & -3.0 & -22 & -12 & $9 \%$ & $29 \%$ \\
\hline Minority & 521 & 85 & -5.3 & -6.0 & -14 & -16 & $37 \%$ & $24 \%$ \\
\hline
\end{tabular}

Source: Authors' analysis of BPS data. Standard deviation of LSAT scores among white matriculants is 5.0.

The final columns of the table offer an indication of what this might mean for black students' class ranks. We rank the students in each cluster by their admissions index values and compute the mean rank of black students in both the actual and simulated pools of matriculants. The entering credentials of the average black student in the elite cluster place her at the $14^{\text {th }}$ percentile of her class. Black students are similarly mismatched in the other clusters, with the average black rank ranging between the $9^{\text {th }}$ and $16^{\text {th }}$ percentiles in all but the "minority" cluster. The average rank of black students would improve with a shift to race-blind admissions, but would remain low, between the $24^{\text {th }}$ and $29^{\text {th }}$ percentiles. This overstates the size of the gap at any individual school — clusters are more heterogeneous than the schools they contain — but nevertheless seems likely to approximate the effect of a shift to race-blind admissions.

Even with race-blind admissions, then, black students' credentials would substantially lag those of their white classmates. Thus, even if the black-white gaps identified in Part V are due entirely to the effects of academic mismatch, it is quite optimistic to assume that they would disappear. We nevertheless assume this in our final simulation. 
Part VI. How Does It All Add Up? Does Affirmative Action Increase the Number of Black Lawyers?

As a final exercise, we combine our estimates of the effect of affirmative action on the number of admitted black students (from Part V) with those of mismatch (from Part IV) into a simulation of the total effect of preferences on the number of black graduates, bar entrants, and beginning associates at large firms. We assume that with race-blind admissions black students would obtain not only the same admissions outcomes as white students with the same entering credentials, but also the same graduation, bar passage, and employment rates. We have discussed three likely biases in this simulation: 1) black-white gaps in law school outcomes likely overstate the importance of mismatch effects (Part III); 2) our simulation of race-blind admissions likely overstates the number of black students who would be admitted to law school (Part V); and 3) a shift to race-blind admissions would not eliminate gaps between the academic credentials of black students and their white classmates (Table 5.3), so we should not expect that any mismatch effects will disappear. Each of these factors will bias our simulation in the same direction, leading us to overstate the number of black students who would reach each stage of the process without benefit of preferences. Nevertheless, we believe the simulation can be informative, as even with these biases it paints a stark picture of the results of a shift to raceblind admissions.

\section{TABLE 6.1: EFFECTS OF ELIMINATING AFFIRMATIVE ACTION AND UNDERPERFORMANCE ON THE PRODUCTION OF BLACK LAWYERS}

\begin{tabular}{|c|c|c|c|c|c|}
\hline & $\begin{array}{r}\text { Status } \\
\text { quo }\end{array}$ & $\begin{array}{r}\text { Change in } \\
\text { admissions } \\
\text { (w/ observed } \\
\text { success rates) }\end{array}$ & $\begin{array}{r}\text { Eliminate } \\
\text { under- } \\
\text { performance }\end{array}$ & New total & $\begin{array}{l}\% \text { change } \\
\text { from current }\end{array}$ \\
\hline & (1) & (2) & (3) & (4) & (5) \\
\hline Matriculate & 2,928 & $-1,851$ & -- & 1,077 & $-63 \%$ \\
\hline Graduate & 2,371 & $-1,454$ & +39 & 955 & $-60 \%$ \\
\hline Attempt bar & 2,159 & $-1,314$ & +39 & 885 & $-59 \%$ \\
\hline \multicolumn{6}{|l|}{ Pass bar } \\
\hline 1st attempt & 1,349 & -748 & +120 & 721 & $-47 \%$ \\
\hline Ever & 1,695 & -978 & +85 & 801 & $-53 \%$ \\
\hline Good job & 700 & -366 & -32 & 301 & $-57 \%$ \\
\hline Large law firm job & 272 & -117 & -14 & 142 & $-48 \%$ \\
\hline
\end{tabular}

Source: Authors' analysis of BPS and grid data. 
Estimates are presented in Table 6.1. The first column shows the number of black students in the 1991 cohort who cleared various hurdles. 2,928 black students matriculated, of whom 2,371 graduated, 1,695 passed the bar exam, and 272 were employed with large law firms four to six months after their scheduled graduation.

The remaining columns of Table 6.1 carry out the simulation. We divide the change in the number of black students clearing each hurdle into two components. Column 2 shows the change in the number of black students reaching each threshold that would arise simply from excluding many current black students from law school, with no change in the success rates of those black students who remain. Column 3 shows the additional change that would result from closing black-white gaps in success rates among the students who would attend law school without affirmative action. Column 4 combines the baseline numbers in column 1 with the changes in columns 2 and 3 to show the number of black students who would reach each threshold in the simulation. Lastly, Column 5 shows the percentage change associated with moving from the status quo to the simulation.

As noted earlier, without race preferences, roughly one-third as many black students would matriculate in law school as are seen today. The excluded students would come disproportionately from the bottom of the pool, where success rates are low. Still, Figures 5.25.4 indicate that substantial fractions of even the black students with the lowest credentials are successful. The elimination of preferences would thus substantially reduce the number of black law graduates, bar entrants, and law firm associates, as shown in Column 2. The number of black law matriculants would decline by 1,$851 ; 1,454$ fewer black students would graduate; 978 fewer would pass the bar exam, 366 fewer would get good jobs ${ }^{123}$; and 117 fewer would begin associate positions at large law firms.

These effects arise simply from the exclusion of many black students from the pool of law students. They would be partially offset if the elimination of preferences would be accompanied by large increases in the success rates of those black students who would remain. Even so, Column 3 shows that the offsetting effect is quite small. Those black students who would attend law school under race-blind admissions would have stronger average credentials than do the black students who currently attend law school. As the results in Table 5.2 indicate, black

${ }^{123}$ See infra note 104. 
students with strong entering credentials do not currently underperform to any substantial degree. Thus, Column 3 indicates that elimination of mismatch effects would add only 39 black law school graduates and 85 bar entrants. Moreover, because black students currently enter prestigious jobs at higher rates than do whites with similar credentials - that is, blacks overperform on this dimension - the elimination of black-white gaps would reduce the number of black graduates who obtain good jobs by 32 and large law-firm jobs by 14 .

Columns 4 and 5 show the overall results of our simulation. Even overstating mismatch effects and understating the importance of preferences to enrollment, the effects of eliminating mismatch are dwarfed by the first-order effect of eliminating preferences, the reduction in the number of black students admitted. The number of black law graduates would fall by 60 percent, while the numbers of bar entrants and large-firm associates would each fall by half.

It is important to emphasize that this analysis focuses on the number of successful black students, not on the success rate. A shift to race-blind admissions would increase the measured success rate substantially. While 58 percent $(1,695 / 2,928)$ of black matriculants in 1991 eventually passed the bar, the bar passage rate would have been 74 percent $(801 / 1,077)$ with race-blind admissions. But this increase would not come primarily from the elimination of mismatch. Rather, most of the change would come from changes in which black students attend law school. The primary determinant of low black success rates is the inclusion among matriculants of students with low LSAT scores and GPAs, most of whom would not be admitted to any law school without race-based preferences. This raises the measured success rate of those black students who are admitted in our race-blind simulation purely through changes in the group over which this rate is computed. ${ }^{124}$

\footnotetext{
${ }^{124}$ One way to see this is to retain the excluded students - those who attend law school in our data but would not have done so without preferences - in the calculation, treating them as not having passed the bar exam. Doing so, we find that the elimination of preferences would have reduced the fraction of would-be black law students who eventually pass the bar exam by substantially more than half.
} 


\section{Part VII. What Has Changed Since 1991?}

All of the statistics presented thus far pertain to the class that entered law school in Fall 1991. An important question is how our results would change if our methods were applied to more recent data.

The applicant pool has changed since 1991, but the relevant changes have been modest. Figure 7.1 shows the fraction black in each of 12 LSAT bins for 2003-2004 applicants, using the modern 120-180 scale. The black share has risen throughout the distribution (as compared with Figure 2.1), though the increase at the top of the distribution is fairly small. Among students scoring above 170 (corresponding to 46 in the old scale ${ }^{125}$ ), the black share has risen from 0.8 percent in 1990-1991 to 1.5 percent in 2003-2004. Still, the black-white gap in admissions qualifications remains extremely large: Black students represent 10.6 percent of all applicants but only 3.2 percent of applicants in the upper third of the LSAT distribution (i.e. with scores of 155 and above).

${ }^{125}$ To align the old and new score scales, we can identify scores that correspond to the same point in the distribution in the two years. Thus, for example, 2\% of LSAT-takers in 1990-1991 scored 46 or above; in 2003-2004, 2\% scored 170 or above. See the discussion in footnote 48, infra. This calculation uses data from several sources: The LSAC NATIONAL STATISTICAL REPORT, 1999-00 THROUGH 2003-2004 (for LSAT distributions of black and white applicants in 2003-2004); Stilwell, supra note 48 (for converting 2003-2004 LSAT scores to percentiles; Barnes and Carr, supra note 45 (for LSAT distributions of black and white applicants in 19901991); and Luebke, supra note 48 (for converting 1990-1991 LSATs to percentiles). 
Figure 7.1: BLACK SHARE OF 2003-2004 BLACK AND WHITE LAW SCHOOL APPLICANTS, BY LSAT SCORE RANGE

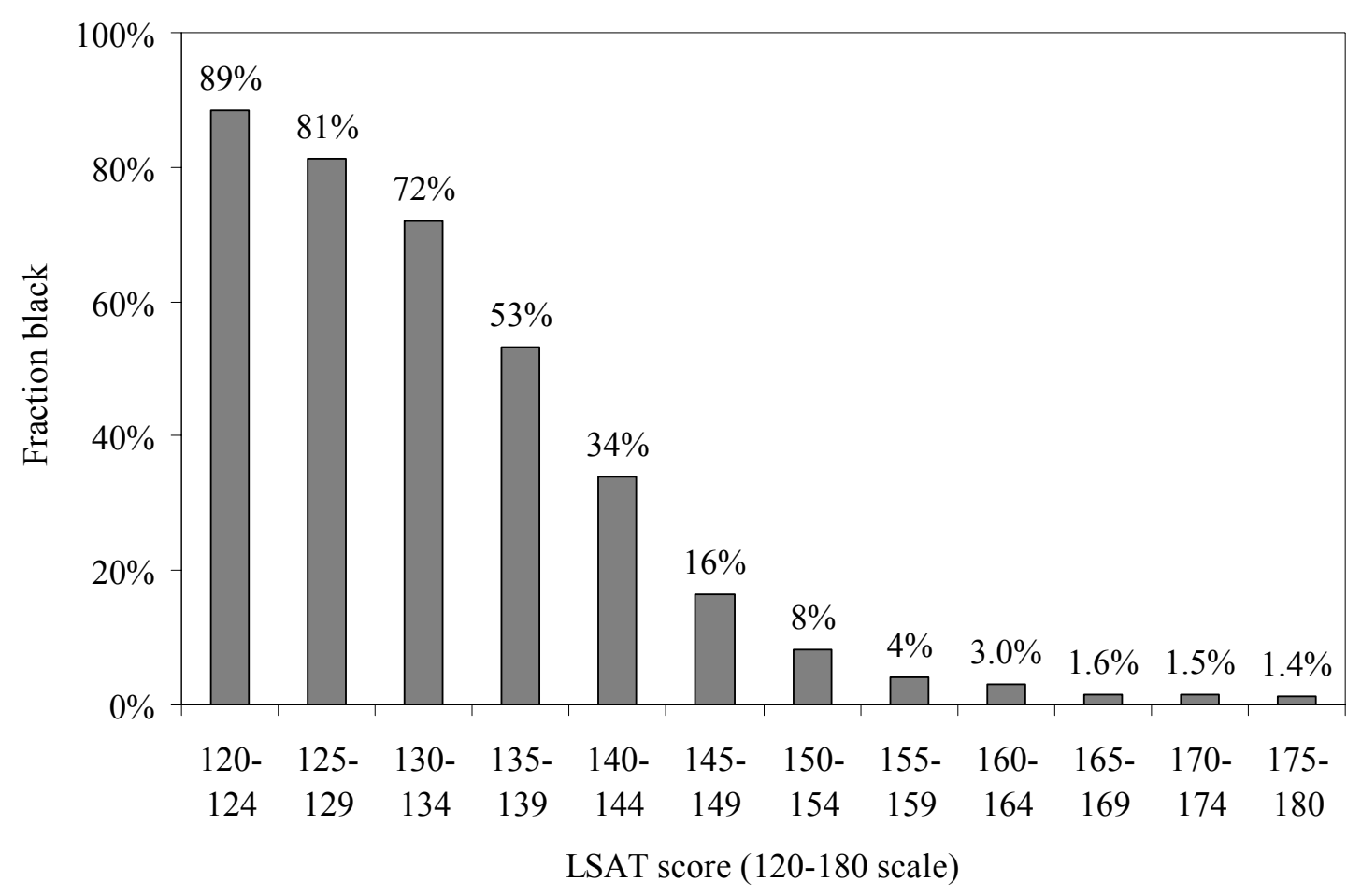

Source: LSAC NATIONAL StATISTICAL REPORT, 1999-00 THROUGH 2003-04.

We can also reproduce the Sander Index percentile scores in grid data from other years. Figure 7.2 shows the fraction of applicants in each grid cell who were black in 1975-6, 1990-1, and 2003-4. The black share of applicants has grown over time throughout the distribution, with particular increases among applicants with percentile scores below 50. The number of black applicants with the highest academic credentials (above the $80^{\text {th }}$ percentile) was somewhat larger in 2003-4 than in 1990-1, but remained quite small in absolute magnitude. 


\section{Figure 7.2: BLACK SHARE OF APPliCANTS in EACH GRID CELL, 1975-6, 1990-1, AND 2003-4}

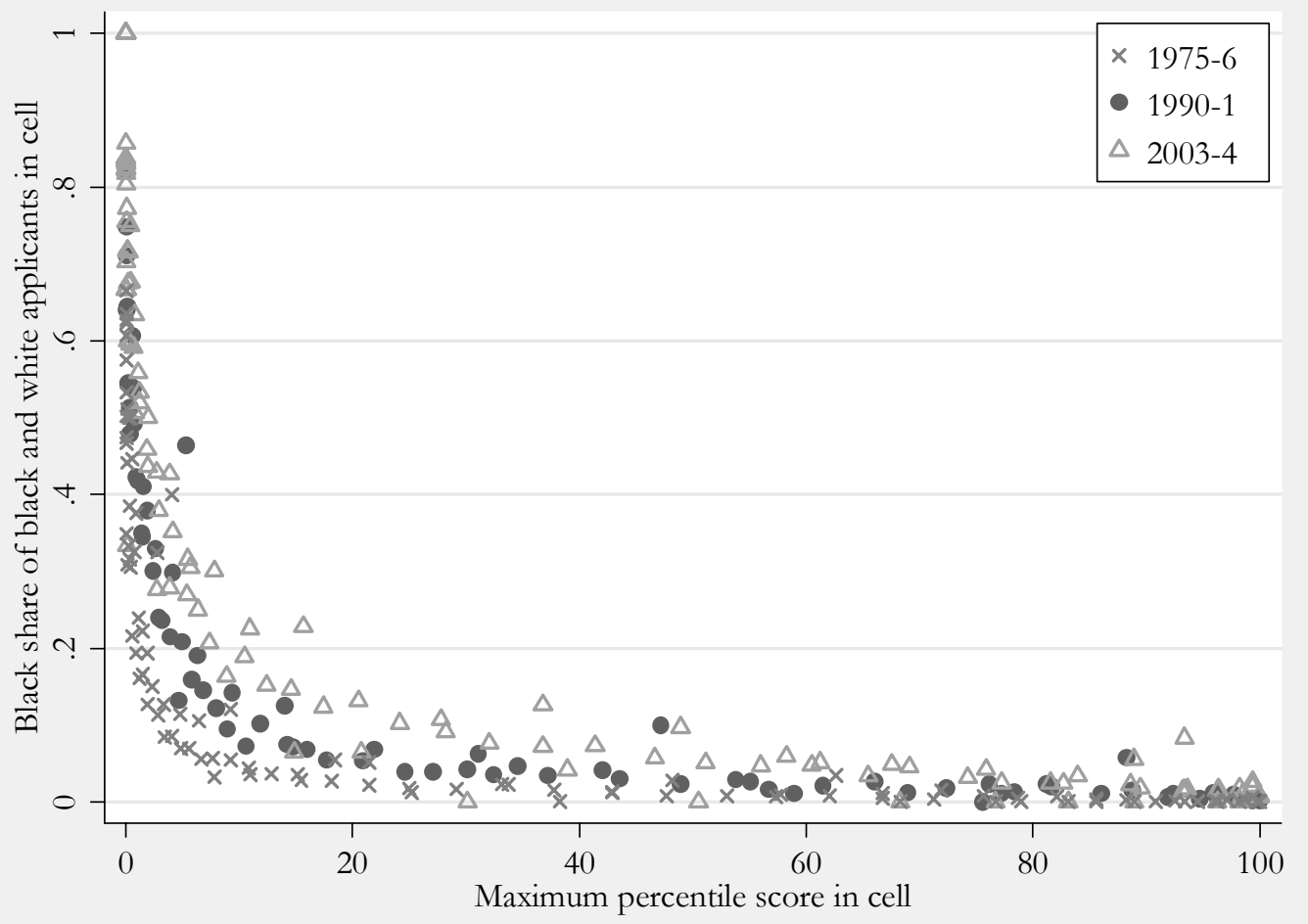

Source: Evans, supra note 112, at 31 (providing data on 1975-1976 cohort); Barnes and Carr, supra note 45/ (for 1990-1991); Memorandum from Robert Carr and Judy Florek (Law School Admission Council) to "Admission Officers" (December 2004) (on file with authors) (for 20032004). We attempt to put all three years' LSAT scores onto a common scale, though this process is subject to error.

Linda Wightman used grid data for 2000-01 to perform a simulation similar to what we presented in Table 5.2. Her results indicated that race-blind admissions would have only excluded 14 percent of black students who were admitted in that year, ${ }^{126}$ a much lower figure than the 63 percent of black students that we conclude would have been excluded in 1990-91. ${ }^{127}$ This difference appears to reflect two factors: one, an increase in the number of black applicants with LSAT scores in the lower middle of the distribution, as indicated by Figure 7.2; and two, a lower admissions standard in the early 2000s due to a reduction in the number of white

${ }^{126}$ See Wightman, Revisiting, supra note 112, at 243 tbl. 7.

${ }^{127}$ For 1990-1991, Wightman's grid model estimates indicate that 1,631 black students would have been admitted without preferences, nearly identical to our estimate of 1,615. See Threat to Diversity, supra note 15, at 22 tbl. 5. 
applicants. ${ }^{128}$ There has been relatively little increase in the number of black applicants with high LSAT scores, and it seems likely that if our simulation of the distribution across types of schools could be conducted for 2001 applicants the results would be similar to those for 1991 . Moreover, Chambers et al. argue that white applications were anomalously low in 2000-2001, and provide evidence that suggests that much larger fractions of black students would have been excluded by a shift to race-blind admissions in more recent cohorts. ${ }^{129}$ Thus, while our simulations would not be quite as dramatic for recent cohorts, it is clear that affirmative action remains a significant contributor to the maintenance of racial diversity in law school.

We know very little about how mismatch effects might have changed over time. It is worth noting, however, that the benefits that might derive from reduced mismatch necessarily shrink as black-white gaps in admissions probabilities shrink: The anti-mismatch consequences of a reduction in preferences arise only by denying students access to schools to which they are currently admitted; if preferences have smaller effects on where black students are admitted than they did in 1991, elimination of those preferences must necessarily have smaller effects on the degree of mismatch. Thus, our bottom-line result that preferences increase rather than reduce the production of black lawyers does not seem likely to have changed since 1991.

\section{Conclusion}

Debates over the effects of affirmative action, and the mismatch hypothesis in particular, in legal education have recently broken out of the academic literature into the broader national debate. ${ }^{130}$ This article attempts to clarify several misconceptions that have arisen in the academic and public debates. We find that:

${ }^{128}$ See Chambers et al., supra note 8, at 1860-1861.

${ }^{129} \mathrm{Id}$., at 1861 .

${ }^{130}$ See, e.g., Adam Liptak, Lawyers Debate Why Blacks Lag at Major Firms, N.Y. TIMES, (Nov. 29, 2006), at 1; Peter Kirsanow, The Big Lie of Diversity, NAT'L. REV. OnLINE, November 14, 2006 (writing that "preferential admissions cause black lawyers to flunk out at two-and-a-half times the rate of whites"); Heather MacDonald, Elites to Anti-Affirmative-Action Voters: Drop Dead, 17 CITY J. 14-29 (Winter 2007) (writing that "affirmative action actually decreases the diversity of the bar.") 
1. Race-based preferences have large effects on the number of black law students, and thereby on diversity in law schools. This result is particularly salient given the Court's pronouncement in Grutter that diversity is a legitimate justification for affirmative action. In the absence of affirmative action, we estimate that the number of black students entering law school would fall by about 60 percent, while black representation at the most selective schools would fall by 90 percent. The decline in black representation would extend well beyond the most selective schools; all but the least selective schools would enroll one-third to one-half fewer black students than they do today. This contradicts claims about the centrality of the so-called "cascade effect," whereby affirmative action affects diversity only at the elite schools. ${ }^{131}$

2. Black students are notably less likely to graduate from law school or to pass the bar exam than are white students. About half of the black-white gap is attributable to differences between the entering credentials of black and white students. Only the remaining half remains to be explained by mismatch effects or other determinants of black underperformance. ${ }^{132}$

3. There is little evidence of underperformance among black students with entering LSAT scores and undergraduate GPAs above those of the $20^{\text {th }}$ percentile student. Although only 26 percent of black students in law school fall into this category, the fact that they succeed at rates comparable to those of white students with similar entering credentials - despite attending much more selective law schools - casts doubt on the mismatch hypothesis, particularly as it applies to elite schools.

4. By contrast, black students with low entering credentials do underperform. None of the evidence presented here or elsewhere, however, has established that this

${ }^{131}$ See Sander, Systemic Analysis, supra note 6, at 417 (writing that "the only schools that truly benefit from the preferential policies are those at the top-perhaps the top forty law schools .... At the bulk of law schools, the very large preferences granted to blacks only exist in order to offset the effects of preferences used by higher-ranked schools.") Even Sander's critics overstate the importance of the cascade effect. See Chambers et al., supra note 8, at 1896 (writing that eliminating preferences would cut black enrollments "by over two thirds at the most selective fifty or eighty law schools").

132 Contrast with Sander, Reply to Critics, supra note 30, at 1968 (writing that the "debate is whether the credentials gap explains $85 \%, 95 \%$, or $100 \%$ of the gap.") 
underperformance is due to mismatch. We have highlighted one alternative explanation, that the observed pattern may be a statistical artifact of the fact that many white students with low credentials are not admitted to any law school. We have not demonstrated it, however, and there are several other viable explanations. ${ }^{133}$

5. Despite previous claims to the contrary, ${ }^{134}$ there is no evidence of black underperformance on any employment outcomes. Perhaps as a result of employers' own affirmative action programs, black law graduates are more likely to obtain good jobs than are white graduates with the same entering credentials. Black graduates also earn substantial salary premia.

6. There is no plausible interpretation of the data under which the elimination of affirmative action would increase the number of black lawyers, ${ }^{135}$ or even decrease it by a small amount. ${ }^{136}$ Rather, a shift to race-blind admissions would have reduced the number of blacks from the cohort studied here who become lawyers by over $50 \%$.

What is the import of these results for policy? None contradict the large gaps in success rates between entering black and white law students. 19 percent of black students who start law school fail to graduate, and only 57 percent become lawyers. This is a potentially serious problem, not least because these students incur large costs in their failed attempts at law. But our analysis suggests that mismatch effects are not an important part of this problem, nor will eliminating affirmative action provide the solution.

The primary impediment to the production of black lawyers is the shortage of highlyqualified black students in the pipeline leading toward law school. As we noted earlier, black-

\footnotetext{
${ }^{133}$ See infra note 92 and the surrounding text.

${ }^{134}$ See Sander, Systemic Analysis, supra note 6, at 466 (writing that the effect of racial preferences on the job market is "overwhelmingly negative").

${ }^{135}$ See $i d$. at 474 (writing that "the absolute number of black law graduates passing the bar on their first attempt...would be much larger under a race-blind regime") and at 372 (claiming that "race-blind admissions would produce an $8 \%$ increase in the number of blacks passing the bar each year.").

${ }^{136}$ See, e.g., Chambers et al, supra note 8, at 1857 (writing of the decline in the number of blacks entering the bar would "be in the range of 30\% to 40\%."). Sander, Systemic Analysis, supra note 6, at 2015, characterizes Chambers et al. as making "the most apocalyptic assumptions possible." Our estimates, which derive from Sander's own assumptions and a more straightforward implementation, indicate that Chambers et al. were in fact substantially conservative.
} 
white gaps emerge in the earliest years of schooling, or even earlier. ${ }^{137}$ A long term solution to the issues investigated here will have to involve closing these gaps, which unfortunately are poorly understood and dismayingly persistent. ${ }^{138}$

Given the shortage of highly-qualified black applicants, many law schools—not just the elite schools, but less selective schools as well-use sizable admissions preferences, taking chances on black applicants who do not meet their ordinary admissions standards. For less selective schools, this means admitting students who would not otherwise have had the opportunity to attend law school. Some of these students are unsuccessful. But a significant percentage do succeed. Crucially, the high rate of failure cannot be interpreted as an indication that these students are mistreated by the affirmative action apparatus. Rather, it simply indicates that not all chances work out.

Given our findings, it is reasonable to ask whether law schools serve students' best interests by admitting applicants with low academic credentials, or whether these students would be better off not attending law school. Unfortunately, our analysis cannot answer this question. For a student with a relatively low probability of success, entering law school can be seen as entering a lottery. Whether this lottery is a sensible choice for any particular student depends entirely on her other options. A student with undesirable non-law-school options may well find law school a worthwhile risk. In any event, there is no reason to think that legal educators are in better positions to make this decision than are students themselves. To facilitate informed decisions, however, students should perhaps be provided with more complete information about the success rates of entering law students with various credentials.

Other steps might be aimed at improving the chances of students who do decide to attend law school, or at reducing the cost of failure. Examples of the first might include efforts to make the law school culture more welcoming or tutoring programs to help all under-achieving students. To reduce the costs of failure, the legal academy might consider programs to forgive

137 See Phillips et al, supra note 52, at 238 (Table 7-2) (documenting a black-white test score gap among students entering elementary school that across several data sets averages around 0.75 standard deviations and grows by as much as 0.2 standard deviations per year thereafter). ${ }^{138}$ See Derek Neal, Why Has Black-White Skill Convergence Stopped?, in HANDBOOK OF ECONOMICS OF EDUCATION (Eric Hanushek and Finis Welch eds., 2006). 
part or all of the debt incurred by students who prove unable to pass the bar exam, thus mitigating the risk to students. ${ }^{139}$

Scholars have debated and will likely continue to debate the merits of the diversity rationale, as articulated by the Court in Grutter. This paper examines affirmative action's contribution to law school diversity and the costs, if any, it imposes on black law students. We find that affirmative action is pivotal in achieving racial diversity in law schools, and that any resulting mismatch effects are concentrated among students who would not be admitted to any law school without preferences. As a policy matter, reasonable people may disagree about whether the costs of "taking a chance" on marginal black applicants outweigh the benefits, and we have little that is new to say about this. Our analysis suggests, however, that one cannot credibly invoke mismatch effects to argue that there are no benefits. Only a small fraction of students who are unsuccessful today would be successful under race-blind admissions. Without affirmative action, the legal education system would produce many fewer black lawyers. Although we do not provide a normative assessment of affirmative action policies, these facts must be part of any informed evaluation.

139 See AMERICAN BAR AsSOCIATION COMMISSION ON LOAN REPAYMENT AND FoRGIVENESS, Lifting the Burden: Law Student Debt as a Barrier to Public Service, The Final REPORT (2003),available at http://www.abanet.org/legalservices/downloads/lrap/ lrapfinalreport.pdf (last viewed March 4, 2007) (explaining law schools' participation in programs that forgive the student loans of graduates who pursue careers in public interest). Of course, loan forgiveness for unsuccessful students would pose different challenges, and we offer it only as a suggestion of a policy avenue worth exploring rather than as a fully developed proposal. 